\title{
Agriculture in northern Namibia, Owambo and Kawango 1965-1970
}

\author{
SYLVI SOINI \\ Agricultural Research Centre, 31600 Jokioinen
}

\section{Preface}

In 1964, the Evangelical-Lutheran Owambo-Kawango Church asked the Lutheran World Federation for an agriculturist and so, by the Finnish Missionary Society I was invited to take up this work. For three years, from May 1965 to June 1968, I worked for the "CDS project 18, Agricultural Survey of Owambo and Kawango". Subsequently, I served as a teacher at the Finnish Mission's private High School of Oshigambo and gave lessons weekly at the Engela Parish Institute.

I would like to warmly thank all the authorities mentioned above, for the opportunity to have worked in these areas. I am grateful to the Neudam College of Agriculture in Windhoek, for analysing soil samples with South African method; to the Agricultural Research Centre, Department of Soil Science in Helsinki, for making Finnish soil tests and other analyses; to the Herbarium in Windhoek and to Prof. H. Roivainen, University of Helsinki, Department of Botany, for identifying plant samples (ROIVAINEN 1974); to Miss Marjatta Elonheimo for her geographical studies which were in close connection with my work and to Dr. Stengel from the Water Affaires Office in the South West African Administration, who granted us an opportunity to study some aeriel photographs of Owambo.

During the first 6 months of my work and some shorter periods later, I received inspiration and guidance about the country and the problems of its people from my interpreter and assistant Mr. Obed T. Embula. My thanks also to the ministers, church members and students of the Engela Parish Institute and the Oshigambo High School, for their information and questions.

In presenting this report I wish to thank Prof. L. Kettunen, agr. R. Hänninen, Mrs Eva Saarela, Miss Merja Manninen, Miss Allison Moore, Mrs. Rauha Kallio and the Agricultural Economics Research Institute for their help in making this publishing possible.

I am grateful to the Scientific Agricultural Society of Finland for including this study in their series of publications.

\section{CONTENTS}

Abstract

1 Introduction

2 General description

21 location

22 climate

23 soils 
24 waters

25 vegetation

26 population

27 economy

3 Soil studies

31 purpose and method

32 terraines and soil types

33 texture

34 soil organic matter

35 soil reaction

36 specific conductivity

37 macronutrients

371 calcium

372 potassium

373 phosphorus

374 magnesium

38 micronutrients

381 manganese

382 iron and zinc

383 other trace element levels

4 Observations and questions concerning farming in the working areas of the Owambo-Kawango Church 1965-1970

41 water supply

411 storage and irrigation

412 prevention of runoff

413 prevention of seepage

414 limiting evaporation

42 plant nutrient supply

421 organic fertilizers

422 artificial fertilizers

43 soil conservation in the veldt

44 farming

441 agronomy

442 gardening

443 nutrive value of some products

444 forestry

445 animal husbandry

45 domestic economy

46 markets

47 human factors

5 Recommendations

6 Summary

References

Selostus

Abstract. The soils of Owambo and Kawango plateau in Northern Namibia between logitudes $14^{\circ}-21^{\circ} \mathrm{E}$ and latitudes $17^{\circ} 23^{\prime \prime}-18^{\circ} 30^{\prime \prime} \mathrm{S}$ are studied applying some methods of the Finnish agricultural soil map work. Soil samples of 120 sites, 76 from 3 depths are analysed, the results are connected with the descriptions of terraines and presented as averages and figures.

This basic knowledge is connected with the facts of references, observations during the period, results of agricultural observation trials, questionaires and discussions with the farmers. According to these the descriptions and suggestions are made concerning the agriculture in the area. Water and plant nutrient supplies, soil concervation and the most possible different branches of the farming life in the area are taken into consideration and $a$ list of these is presented. 


\section{Introduction}

In Owambo, when the first missionaries came about 100 years ago, they existed not only on salaries from Finland, but on the result of their farming. They had to introduce all their own agricultural knowledge and put it into practice along with those customes they were able to accept from the inhabitants. For the new Christians, adjustment to a systematic form of agriculture was fairly easy. When set free of heathen taboos in general, they could learn for example, how to use kraal manure for fertilizing and how to plough with oxen. Kalle Koivu (work period: 1904-47) was a very active farmer to follow as a teacher.

When the Government took over the responsibility for primary school education, there were no separate vocational schools to assume the responsibility of education in agriculture. Thus agricultural education did not proceed at the same pace as at the time when the mission organised it and when teachers of the Church had to take care of their own living partly by cultivating the land. Now the agricultural education could mainly be received from what was included in the government schools study programs.

At the project's beginning, some questions and problems were exposed by $\mathrm{Mr}$. Smith, the Government Officer, some were put by the inhabitants and some came from my studies during the five year period. This work is mainly a preliminary study of the soils, vegetations and farming in the area, connecting theoretical agricultural knowledge to local reality, and some suggestions are made for further investigations of farming in these areas.

The original report on the agricultural survey of Northern Namibia, CDS 18 project of the Lutheran World Federation 1965-68 (-1970) was given 1971 as dubblicates to the Owambo-Kawamgo Church, Lutheran World Federation, Finnish Missionaries Society and the South West African authorities. This version is revised, shortened concerning original analyse numbers and citations and extended in nutritional aspects.

\section{General description}

\subsection{Location}

The working area of the Owambo-Kawango Church is situated between longitudes $14^{\circ}-21^{\circ} \mathrm{E}$ and latitudes $17^{\circ} 23^{\prime}-18^{\circ} 30^{\prime} \mathrm{S}$ in Northern Namibia (Map I and II). This is between the border of Angola in the north and Etoshapan in the south and from Ruacana Falls on the Kunene in the west, to somewhere east of Rundu. In the west, Owambo is 4201000 ha (approximately $125 \times 340 \mathrm{~km}$ ) and the Kawango is 3299617 ha in area. These areas, however, should be increased to an aggregate of $9777250 \mathrm{ha}$, according to the recommendations stated in the Commission of Enquiry Report, in the South-West African Affairs 1962-1963. The altitude of the main are is $1090-1150 \mathrm{~m}$. In Owambo, the watercourses run south to the Etoshapan and east to the Kawango river, from where they turn south at Andara. 


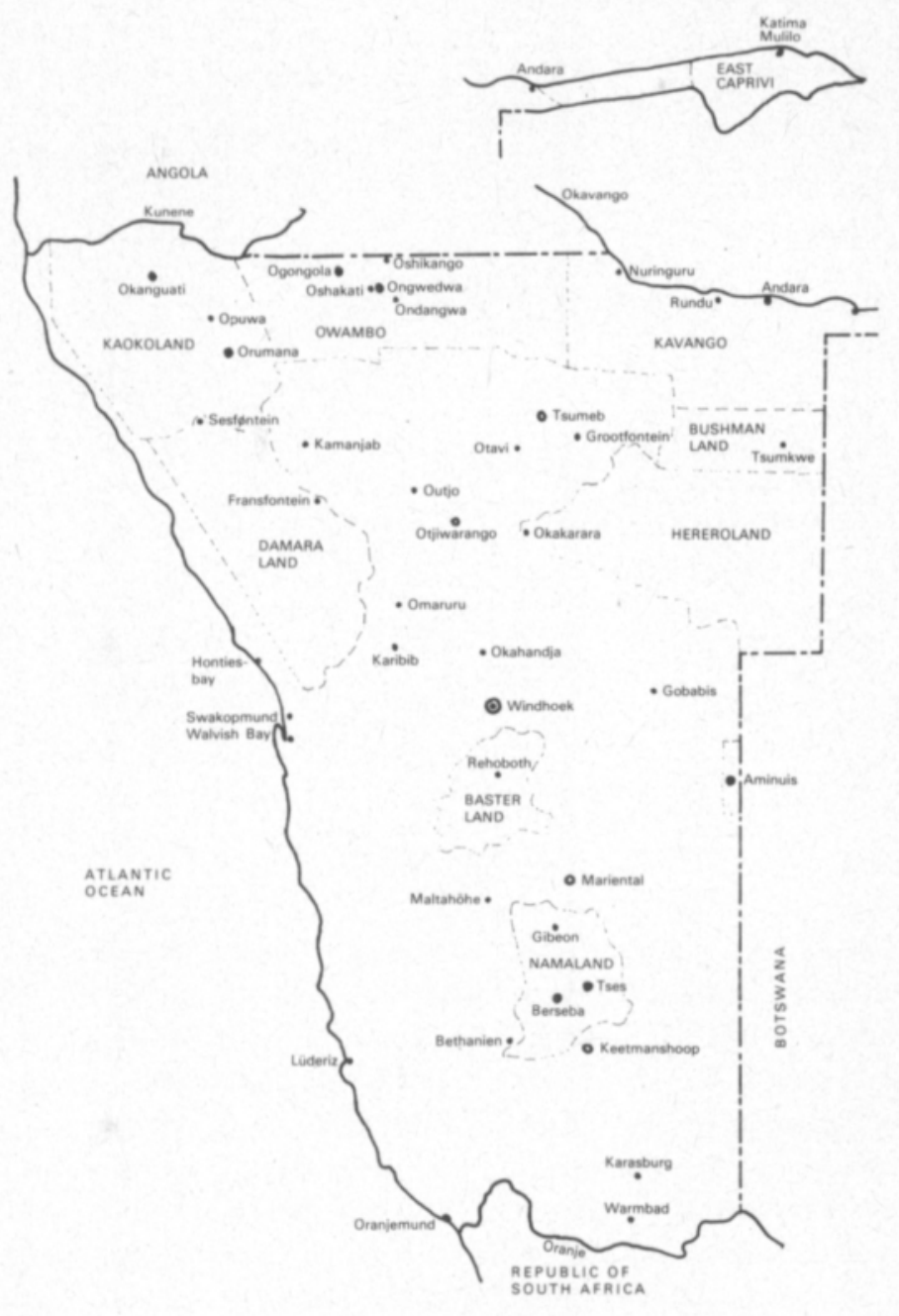

Map I. NAMIBIA.

\subsection{Climate}

It has been described by BARNARD 1964, that the climate of this plateau is more subtropical than what is expected at that altitude. The average temperature in January is about $+25.5^{\circ} \mathrm{C}$ (the highest temperatures are in the middle and northern parts of Owambo) and in July between $+15^{\circ}-+17^{\circ}$ (the highest temperature on the Kawango riverside). The average annual precipitation is $300-500 \mathrm{~mm}$ in western and south-eastern Owambo, $500-600 \mathrm{~mm}$ in the middle and north-east areas and above $600 \mathrm{~mm}$, only in a small area on the Kawango riverside. The average variability of precipitation is about $30 \%$, being somewhat lower than in the west. The average duration of the rainy season (number of months with more than $50 \mathrm{~mm}$ of average precipitation) is 4 months in the west and 5 on the Kawango. The average annual number of rainy days, vary from 30-59 in the west to 60 on the Kawango and there may be thunderstorms between $30-40$ of these days. Approximately $90 \%$ of the average annual precipitation occurs from October 


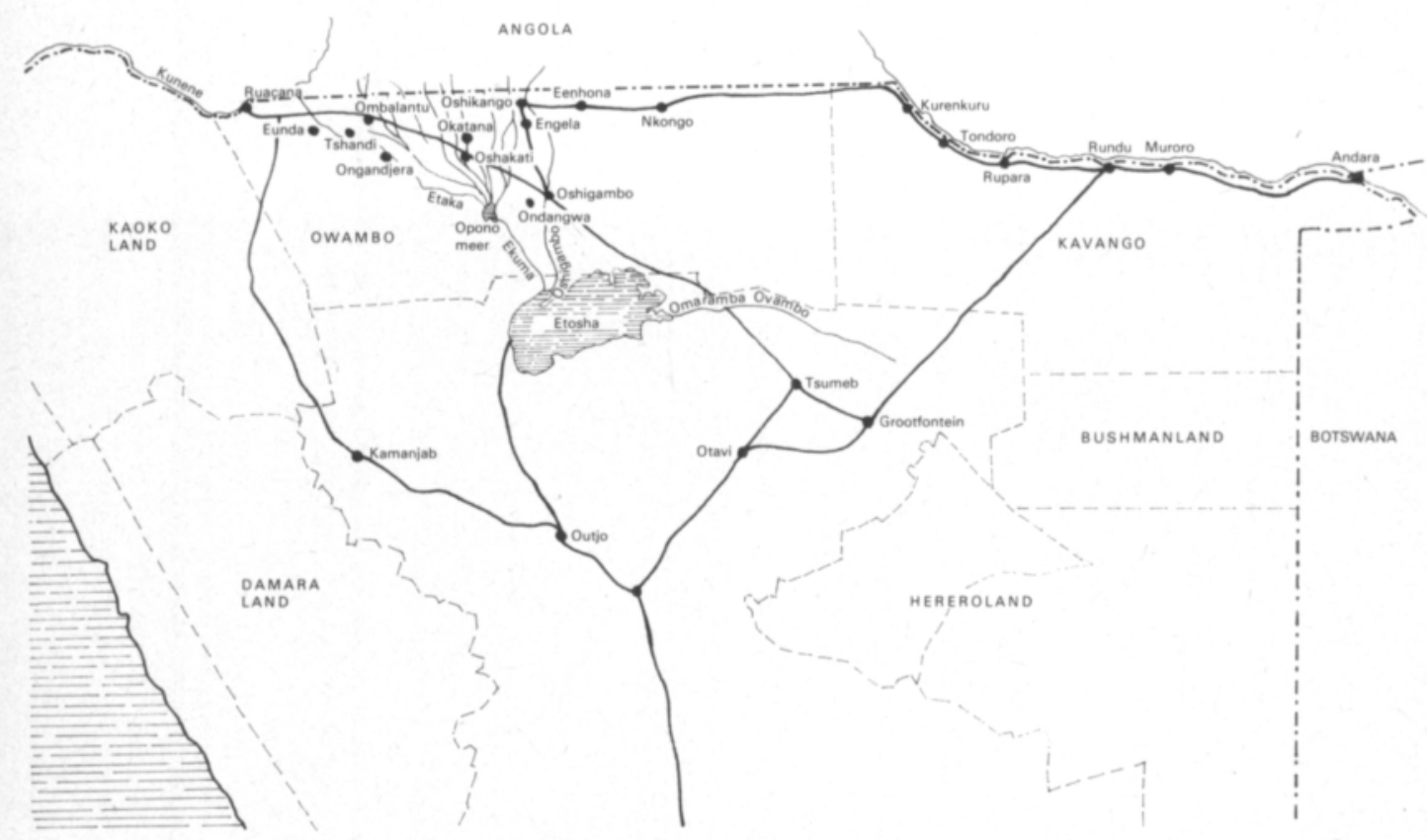

Map II. NORTHERN NAMIBIA.

to March. According to these figures the climate can be classified as a sub-humid climate in the main area and semiarid climates in the west and south-west. Marginal dry cultivation is possible in the main area where the grazing area for one stock unit is approximately $6-8 \mathrm{ha}$. The considerable altitude and daytime temperatures cause evaporation, consequently, dry times can often occur. For example in a period of 20 years, there has been 3 very dry, 3 dry, 9 normal, 1 good and 4 very rainy years. In some years, low night temperatures have caused damages to subtropical and tropical fruit trees and to other cultivated plants, when at a sensitive growing stage. This information is comparable with that of other South African districts by COOKE (1964)

\subsection{Soils}

The soils of the project area belong geologically to the Kalahari system (COOKE 1964). They are sands which may primarily be Pliocene, redistributed during the Quarternary (Pleistocene), comprising chalcedonic limestones, silicified sandstones and ochreous sands (HAMILTON andCOOKE 1960,ANON. 1964). The sandlayers are usually several tenths of meters deep. Original rocks can be seen only several tenths of meters deep. Original rocks can be seen only near the Kunene river.

Precipitated calcerous concretes, known as "white, stones" are found for example under the wild fig tree (Omukuyu gwemanya $=$ stone fig tree) on the Oshigambo river (Ondonga, Fig. 1 a), in the middle field subsoil of Nkongo (Uukuanyama) and in Ombafi (North Uukuambi) under more than $10 \mathrm{~m}$ of loose sand and in some other sites. In earlier dry ages, under the influence of continuous winds from the north-east, these sands have obviously risen from the Kalahari area to the east, forming in the Kawango high longitudinal ridges and later in the east 

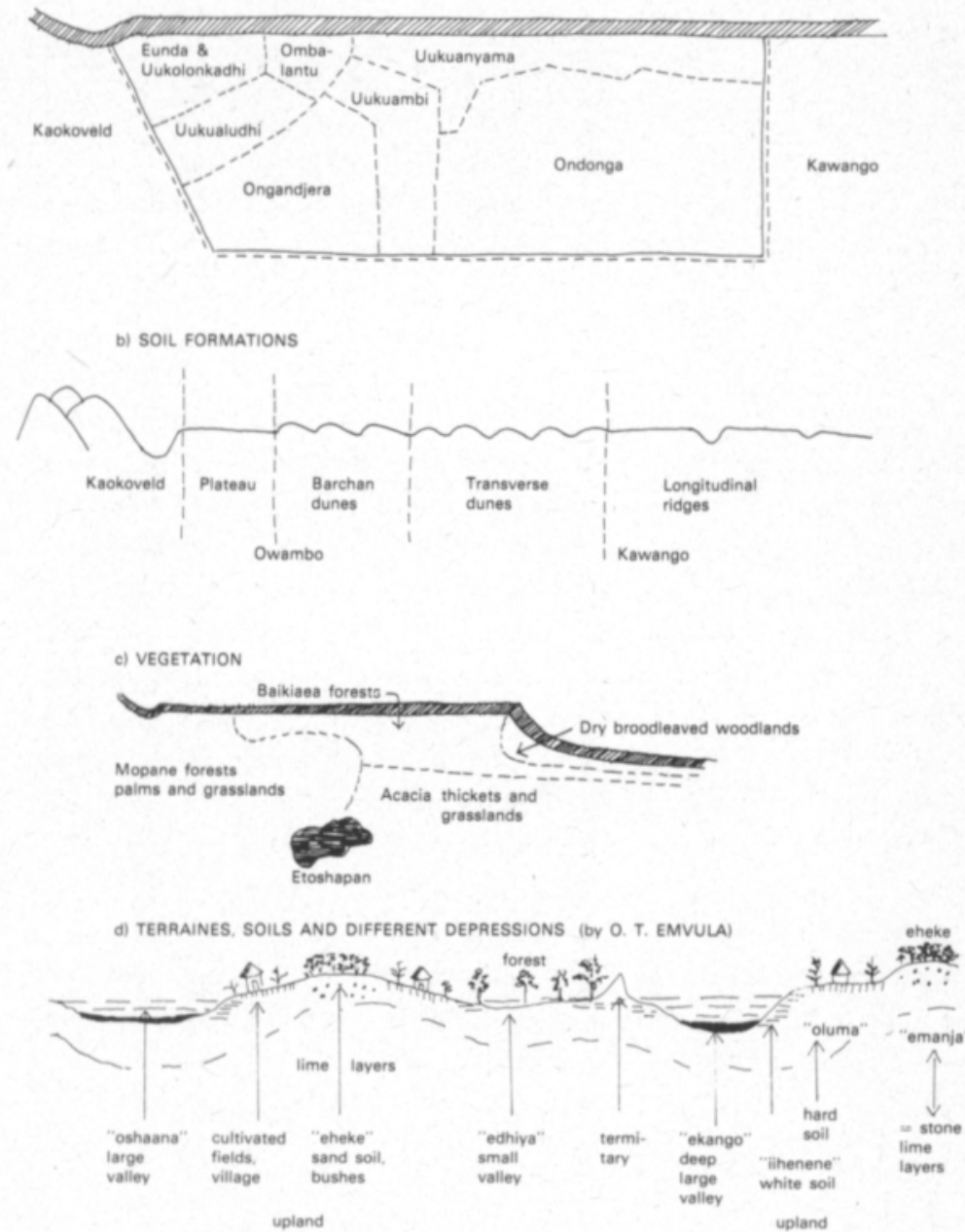

Fig. 1. Different descriptions of Owambo-Kawango area.

and middle of the Owambo transverse and barchan dunes, almost completely vanishing to the west. (Fig. l b). Also these sands have been redistributed by rain and by water from the north of Angola, such as the Guvelai delta. Owing to the moderate precipitation of later years, these formations have turned into uneven plateaus where rain water sometimes covers large valleys (oshanas) between consolidated sand hills.

One description of tropical "plain soils" of East Africa (VINE 1966), when used to describe the Owambo soils, is as follows: calcareous or non-calcareous lightcoloured (pale grey to pale brown) pedocals, usually forming catenary sequences with black calcareous clays in the broad depression in some areas interrupted by red earth". VINE (1966) describes pedocals as being dry region soils, in which $\mathrm{CaCO}_{3}$ and possibly $\mathrm{CaSO}_{4}$ tends to accumulate in the upper layers of the subsoil, while the leaching action of the rain is restricted to the top layers. These belong mainly to the Zonal Soils where effects of climate and vegetation are acting over long periods and dominate over those of parent rock and drainage factors. Anyhow Owambo- 
Kawango area is not calculated as dry but semiarid and subhumid and the lime layers are usually deeper in the subsoil and exceptionally in subsurface. According to PAPADAKIS (1969), the soils west of Owambo are arid brown kaolisols and in east Owambo and the Kawango area, the soils are eutrophic kaolisols. The descriptions of salina or solonized soils with abundat $\mathrm{Na}^{+}$or solonchak soils with $\mathrm{Ca}^{++}$in connection with solid soils with abundant leaching of soluble salts (BRIDGES 1970) may be suitable in description of some varieties of different valley soils in the area.

\subsection{Waters}

Two permanent rivers form borders to the area; The Kunene in the northwest corner and the Okavango along the northern border of the Kawango area and in the middle of Owambo there are temporary rain water systems between the oshanas. In the west it is the Oshana Etaka, in the middle the Cuvelai delta-system and in the mid-east the Oshigambo river. In some years, water from the Angola side (efundja) will occasionally flow through the oshanas of the Cuvelai delta to the Etosha Pan (BARNARD 1966). During the dry season, water is taken for domestic purposes by digging holes often more than ten meters deep to the underground water table.

The South-West African Govenment has built earth dams, in soils which are impermeable and boreholes, where the ground-water is not too brackish. Mr. H. W. Stengel of the Water Affairs Office, suggests that there is a "bitter sea" in the areas of Ombalantu, Mbunda, Uukolankadhi, Enhana, Ohandjwumbali and Omboloka. The government has made plans for canal from the Kunene river to the middle of Owambo to irrigate about 10000 ha and provide water for cattle over 430000 ha (totalling approximately one tenth of Owambo), riverside irrigation using water from the Kawango and if possible, a diversion of water from the Kawango into the Cuvelai in the northern parts of Angola for regular water supplies to the northern parts of Owambo (ANON. 1961,ANON. 1962-63).

\subsection{Vegetation}

There are four different natural types of vegetation (Fig. 1 c) apart from gardenlike or nearly open inahabited areas. From the northwest, along the northern border and norheast to east of Owambo and Kawango, there are forest savannas with Baikiaea plurijuga (Rhodesian kiaat, "omupapa"), Guibourtia coleosperma (Rhodesian mahogany, "uusivi"), Sclerocarya birrea (murula, "ongongo") and others, mostly decidous trees. Even though the rainfall is only $600 \mathrm{~mm}$ in the main forest area from east Owambo to the Kawango, the forest is often the habitat of the Miombo woodland and savanna, which is the driest type of broadleaved woodland and derived savanna formation. In the middle and in most of the western areas of Owambo, there is a mopane (Colophospermum mopane) forest savanna, but the very typical mopane grass savanna can be seen in the western middle part of the country. As the settlements spread makalani palms (Hyphene ventiricosa) have parts of the mopane forests, especially in the Uukuambi tribe area. In the south close to the Etosha Pan, there are ordinary grasslands. The Baikiaea forest savanna moves occasionally to the Combertaceae-Acacia thickets in the southeast, to the northeast side of Etosha and to the southern parts of the Kawango area. The flora of the 
whole area is still quite rich even in herbs and grasses in spite of overgrassing in many inhabited areas.

\subsection{Population}

The population, according to the census of 1960, was 234363 persons in the Owambo and 27871 persons in the Kawango, i.e. $45.5 \%+5.3 \%$ which represents more than half of the whole South West African population. The population is quite heavily concentrated near the waters of the Cuvelai system in middle Owambo (over 8 persons per $\mathrm{km}^{2}$ ) and near the Kawango riverside (4-8 persons per $\mathrm{km}^{2}$, BARNARD 1964).

\subsection{Economy}

Each family supports itself on its own cultivated fields. The fields are commonly about $2-10$ ha per family (Fig. 2-5) and the method of cultivation is by plough and hoe. The main crop is "omahangu" millet (Pennisetum typhoides), while others are "iilyalyaka" (Sorghum sp.), beans, pumpkins, watermelons, legumes, various groundnuts etc. Many native plants are also used as vegetables: onions, leaves, flowers, tuberous roots and water lilies. Some trees and shrubs have been saved near the family's dwelling, as common cultivated fruit trees, decoratives or shadows.

Travelling around the countryside and talking with the inhabitants in 1965-70 it was easy to observe how the hoe was giving way to the plough. A "taboo", expressed in the old religion, demanded that women only hoe fields because of the fertility. With Christianity however such taboos gradually disappeared and the first Christian native to follow the mission workers' example of ploughing the field with oxen, is still alive. The skill of ploughing spread so rapidly, that over half of the families had a plough of their own. In some districts, possibly only $5-10 \%$ of the families prefered to make exclusive use of the hoe in tilling the soil. Initially oxen were used for ploughing, but donkeys were introduced from the south and were used by half of the ploughers. In a few cases, tractors were also used by the inhabitants of Owambo. A large majority of all cases used crop stubble for feeding the cattle and the very best straw for building purposes. However, ploughing-in the stubble is not yet common although burning had become quite rare. Fertilizing is with kraal manure but insufficient in most cases, since when applied in September and ploughed after the first rains of November-December, it loses much nutrient value.

Because of the land tenure system, in which the land belongs to the tribe with only those fields in sight being granted for new cultivation, the main tribal areas have become densely populated. In addition, the forests have been cut down and common pastures between fields are overgrazed. Some tribes however, have spared certain fruit trees to provide shade and these trees have given the tribal area a special individuality. Only in Ongandjera, the fruit trees have not been spread, the reason being that not only their fruit but also the surrounding fields may belong to the headmen. In the peaceful times, people have been able to acquire new fields from forests, near larger grazing areas or from districts bordering other tribes and even within the areas of other tribes. The government has also made such migrations easier by providing dams and boreholes in those districts. 
The livestock population of 828930 head (large and small livestock) represents a stocking rate of 6.7 ha per head (ANON. 1962-1963), although the carrying capacity of the fields is $6-8$ ha per head (large livestock). Cows, goats and hens are the most common domestic animals together with donkeys and pigs. Sheep are seen only in the west and horses are most uncommon. Animal husbandry based solely on natural grazing has always been the practice of the inhabitants and government has for many years attempted to develop this kind of farming by providing water supplies, veterinary help and organizing the grazing customs and markets. In addition income can be earned from sale of handicrafts since many homemade household articles have become marketable and sales could be increasing in the special articles for men and women made from wood, palm leaves or clay.

The possibilities for agriculture are considerably better than in other parts of South West Africa (apart from Tsumeb and the Grootfontein districts). However other natural resources seem to be limited to various kinds of valuable trees, to possible coal findings near Etosha and salts in Etosha. As part of its policy of support and development, the government has begun to execute industry and marketing plans for the homelands (ANON. 1962-1963). As a result, Owambo home transport and trade has been developing rapidly with income entering the area from contract workers, working outside the homeland even though their salaries were not high. Money used by the government for area development is also in some cases used to pay the wages of the inhabitants.

\section{Soil studies}

\subsection{Purpose and method}

This study aims to supply some basic details on the soils of Owambo and Kawango. To determine the textures and fertilities of soils, 283 samples were collected from 120 sites. $^{1}$ Seventysix samples represented the surface $(0-20 \mathrm{~cm})$, subsurface $(20-40 \mathrm{~cm})$ and subsoils $(40-60 \mathrm{~cm})$ and were examples of different types of terrain from each main tribe area (Fig. 1 a). The particle size distribution was determined from 64 samples by wet and dry sieving, as well as by the pipette method. The results are presented in table 1 . The names of the soil types follow the system presented by AALTONEN et al. (1949), which is based on texture. The exchangeable $\mathrm{Ca}$ and $\mathrm{K}$, as well as the readily soluble $\mathrm{P}$ were determined from acid ammonium acetate $(\mathrm{pH} 4.65)$ by a method used by VUORINEN and MÄKITIE (1955). The soils' $\mathrm{pH}$ and specific conductivity were determined from a 1: 2.5 soil/water suspension and the organic materials were determined by the bichromate method. The results are presented in tables 2-4. Since the Finnish soil testing method has been developed for acid soils 114 samples were analysed with the South African methods. Nitrogen was analysed by the Kjeldahl Method, phosphorus and potassium extracted, with a $1.0 \%$ citric acid solution and then determined: $\mathrm{P}$ colorimetrically, $\mathrm{K}$ by a flame-photometer.

\footnotetext{
${ }^{1}$ Map of soil sample sites and data of samples are obtainable from the author.
} 
Some drawings were made of soil profiles in averages and are included in this study. The Finnish interpretation table of the soil testing results is also presented in table 5 with the total number of analyses of different soils distributed in these fertility classes presented in table 6 .

The intake of other plant nutrients have recently been found to be important to human health, especially considering sandy soils with intensive cultivation and macronutrient fertilizers (ROSE 1968, MARJANEN 1969). Some other nutrients were consequently analysed from 59 samples: $\mathrm{Mg}, \mathrm{Mn}, \mathrm{Fe}$ and $\mathrm{Zn}$, extractable in acid ammonium acetate ( $\mathrm{pH} \mathrm{4.65)}$ ) with atomic absorption. The results are presented in table 7. Some total microelement contents were analysed: $\mathrm{Co}, \mathrm{Cu}, \mathrm{Mn}, \mathrm{Mo}, \mathrm{Ni}$, $\mathrm{Pb}, \mathrm{Sr}, \mathrm{V}, \mathrm{Zn}$ and $\mathrm{Sn}$. The results as $\mathrm{mg} / \mathrm{kg}$ of dry soil are presented in table 8 .

\subsection{Terraines and soil types}

The author suggests that $\mathrm{Owambo}$ soils have been redistributed by winds since the beginning of the Cuvelai delta formation. Ancient dune formations seem to be observable in the landscape (Fig. $1 \mathrm{~b}$ and d) especially in aerial photographs, such as those taking in the rainy season of 1963 from which four small drawings are

Fig. 2. Ombalantu.

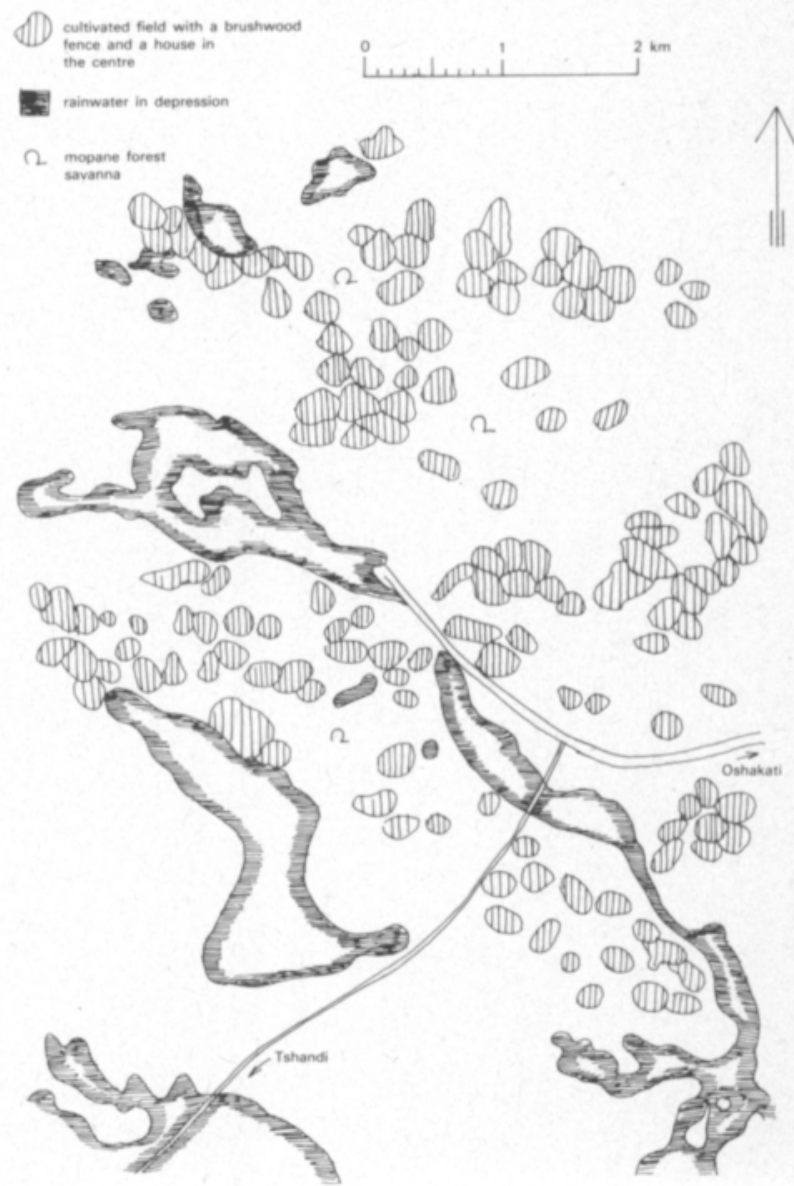


presented. Higher places are not visible in western Ombalantu (Fig. 2), but the water valleys follow the direction of possible transverse dunes. The distinct heights of the ancient barchan dunes can be seen surrounded by cultivated fields near Ogongo (Fig. 3). In northeastern Uukuambi (Fig. 4) the heights of transverse formations can be seen more clearly with their surrounding fields. The rainwaters easily sink into the loose sand at the top of the heights, with calcareous concrete layers consequently appearing deep under the surface. This could be seen in Ombafi, where sand was removed for road work. The concrete layers may expel the water from the sands near the lower edges of the heights and usually, the cultivation is on the edges of these ridges and near the valleys. Near Ondangwa (Fig. 5), the ancient formations are not visible, but the fields are spotted with new erosion hollows or future water dongas or plantless "iipale". The "iipale" extends when wind erosion occurs during the dry season. These formations are connected with a waterrepellence phenomenon in dry sandy soils (McGHIE 1979) and ovegrazing. In Uukuanyama, the heights and valleys are more definite towards the east and north. In the Kawango area, there are quite high and large longitudinal ridges, with large deep intervening valleys.

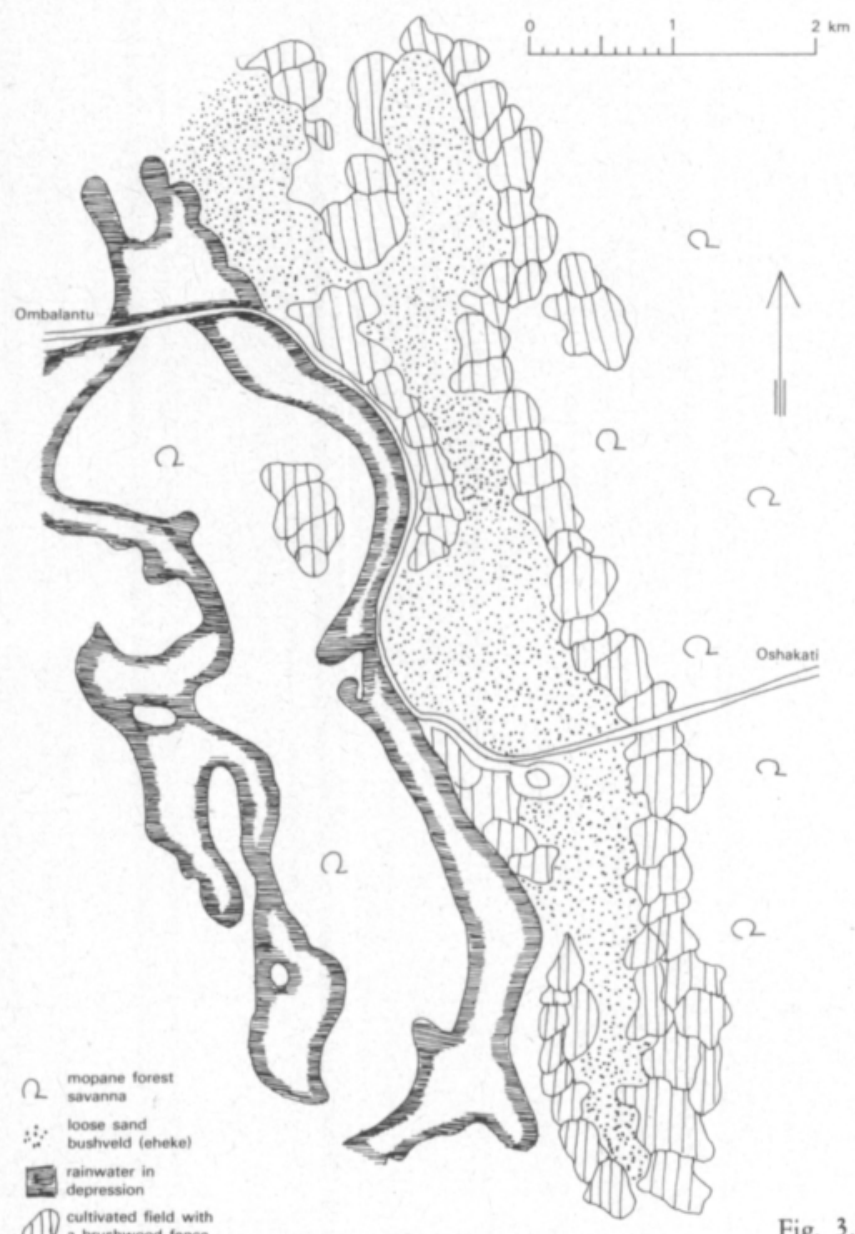

Fig. 3. Ogongo. 


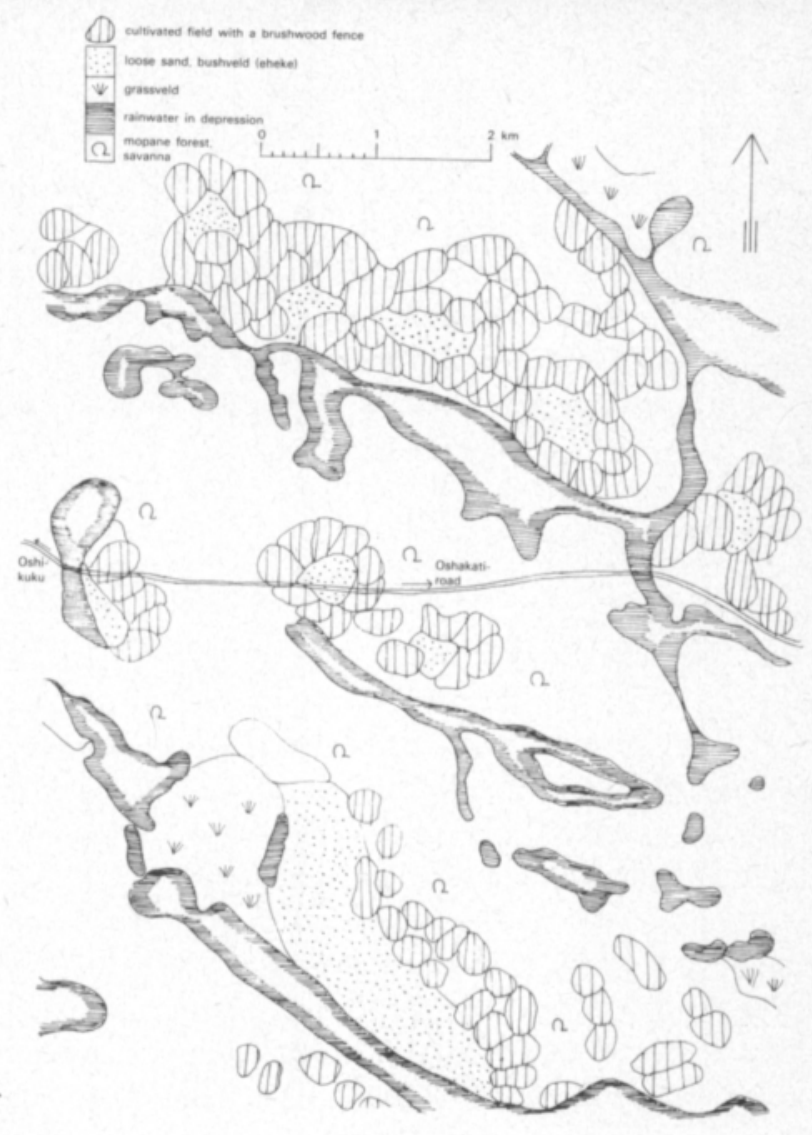

Fig. 4. Uukuambi, north east.

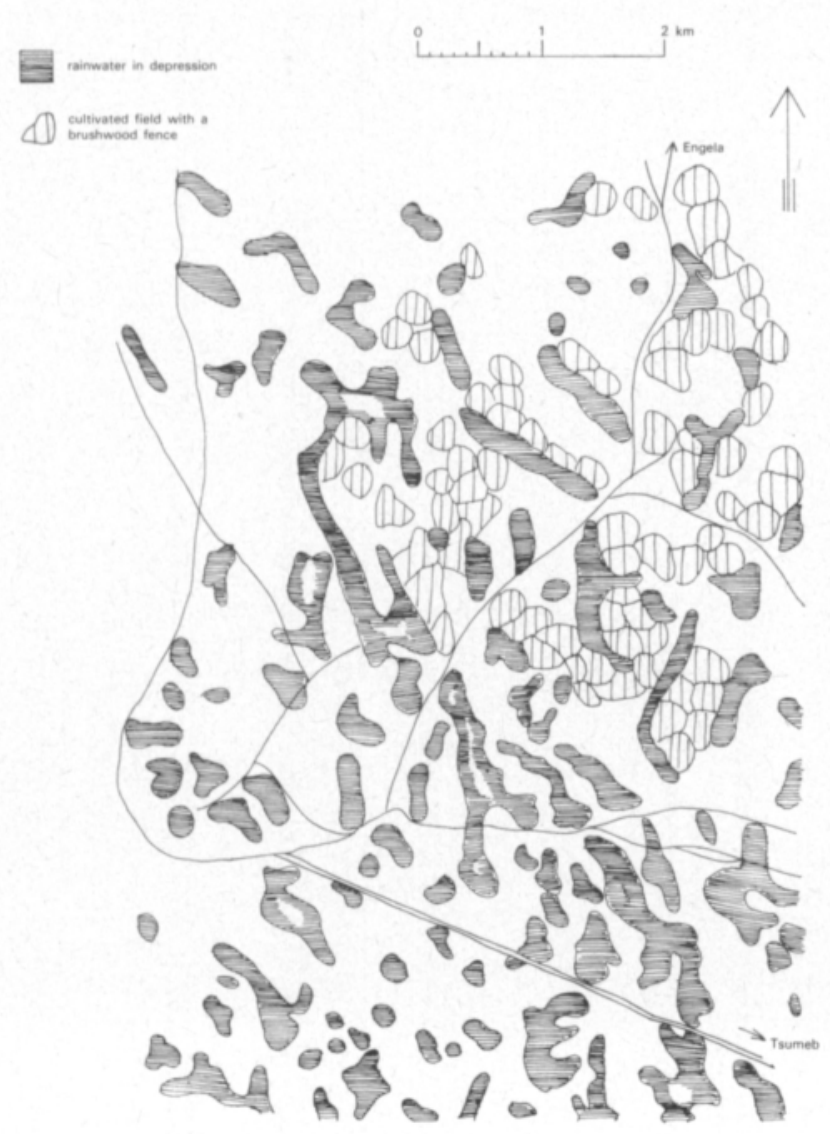

Fig. 5. Ondangwa. 
The most common altitude level for cultivated fields is above the rainwater and may therefore be called uplands. The highest tops of the ancient dunes or uplands can be cultivated, but usually they are uncultivated deep, loose or slightly cemented sands. If they are quite loose, they are called "ehekevi". A little lower than the cultivated level is the very typical mopane forest. It is found on the barely rising (east) sides of the shallow western oshanas. In the very far west, there are large bush savannas with indistinct variations in height.

The oshanas and rivers are at the lowest levels and are called valley soils. They may vary from good grass-growing to quite plantless soils and from loose sand to heavy clay, mixed with organogenic mud and can be both often or seldom covered with running or standing water.

\subsection{Texture}

There is only a slight difference between loose sands and other hight soils. Cultivated and virgin upland soils do not differ, but from west to east they resemble more and more closely "ehekevi", which are sands (Table 1). More than $50 \%$ of them contain sands in amounts above $60 \%$. All of them contain more than $60 \%$ coarse-fine sand to finer-coarse sand mixtures. Nearly half of them contain more than $90 \%$ of this mixture (coarser fine sand triangle Fig. 6). This kind of mixture is closely similar to the particle size distributions analysed in Finland on the soil catena between dunes and alluvial fine sands in the Liminka district. The analyses of loose sands are not similar to analyses of young dune soils, which are $85-95 \%$ finer coarse sands at the top of the dunes and 60-80\% finer coarse sands between heights. According to the South African texture triangle (Fig. 6), the 64 soil samples included 4 clay, 8 sandy clay, 2 loam and 50 sands.

Table 1. The average particle size distribution of analysed soils (Fig. 6 and 7).

\begin{tabular}{|c|c|c|c|c|c|c|c|c|}
\hline \multirow[t]{2}{*}{$\begin{array}{l}\text { Terrain types } \\
\text { and districts }\end{array}$} & \multirow[t]{2}{*}{ Samples } & \multirow[t]{2}{*}{$\begin{array}{c}\text { Clay }(\mathrm{Cl}) \\
0.002\end{array}$} & \multicolumn{2}{|c|}{$\begin{array}{c}\text { Silt (SI) } \\
0.002-0.006-0.02\end{array}$} & \multicolumn{2}{|c|}{$\begin{array}{r}\text { Fine sand }(F s) \\
0.02-0.06-0.2\end{array}$} & \multicolumn{2}{|c|}{$\begin{array}{c}\text { Sand (S) } \\
0.2-0.6-2 \mathrm{~mm}\end{array}$} \\
\hline & & & fine & coarse & fine & coarse & fine & coarse \\
\hline \multirow{2}{*}{\multicolumn{9}{|c|}{$\begin{array}{l}\text { Upland soils } \\
\text { cultivated }\end{array}$}} \\
\hline & & & & & & & & \\
\hline west & 9 & 1.3 & 0.0 & 0.1 & 6.1 & 29.8 & 47.2 & 15.5 \\
\hline east (average) & 10 & & & & 5.0 & 35.9 & 55.9 & 3.1 \\
\hline Ondonga & 5 & & & & 3.7 & 36.1 & 56.4 & 3.8 \\
\hline Uukuanyama & 9 & & & & 5.8 & 35.3 & 56.1 & 2.8 \\
\hline Kawango & 6 & & & & 5.2 & 36.6 & 55.0 & 3.1 \\
\hline \multicolumn{9}{|l|}{ virgin } \\
\hline west & 4 & & & & 6.7 & 33.4 & 45.0 & 14.9 \\
\hline east & 12 & & & & 5.0 & 37.0 & 53.7 & 4.3 \\
\hline loose sand soils & 6 & & & & 3.6 & 33.2 & 56.2 & 7.0 \\
\hline far west savanna & 2 & 5.3 & 0.3 & 0.8 & 5.0 & 55.4 & 31.6 & 1.1 \\
\hline mopane forest & 3 & 13.7 & 0.7 & 0.8 & 5.3 & 22.7 & 35.6 & 21.2 \\
\hline \multicolumn{9}{|l|}{ Valley soils } \\
\hline west & 5 & 22.5 & 4.2 & 8.3 & 9.2 & 19.5 & 25.4 & 10.9 \\
\hline east & 6 & 24.1 & 4.2 & 3.9 & 1.8 & 25.6 & 36.1 & 4.3 \\
\hline bottle clay, Owambo & 2 & 44.9 & 5.7 & 4.6 & 1.6 & 19.9 & 17.8 & 5.5 \\
\hline riverbed, Kawango & 2 & 46.2 & 8.6 & 10.5 & 13.4 & 19.2 & 2.1 & \\
\hline
\end{tabular}



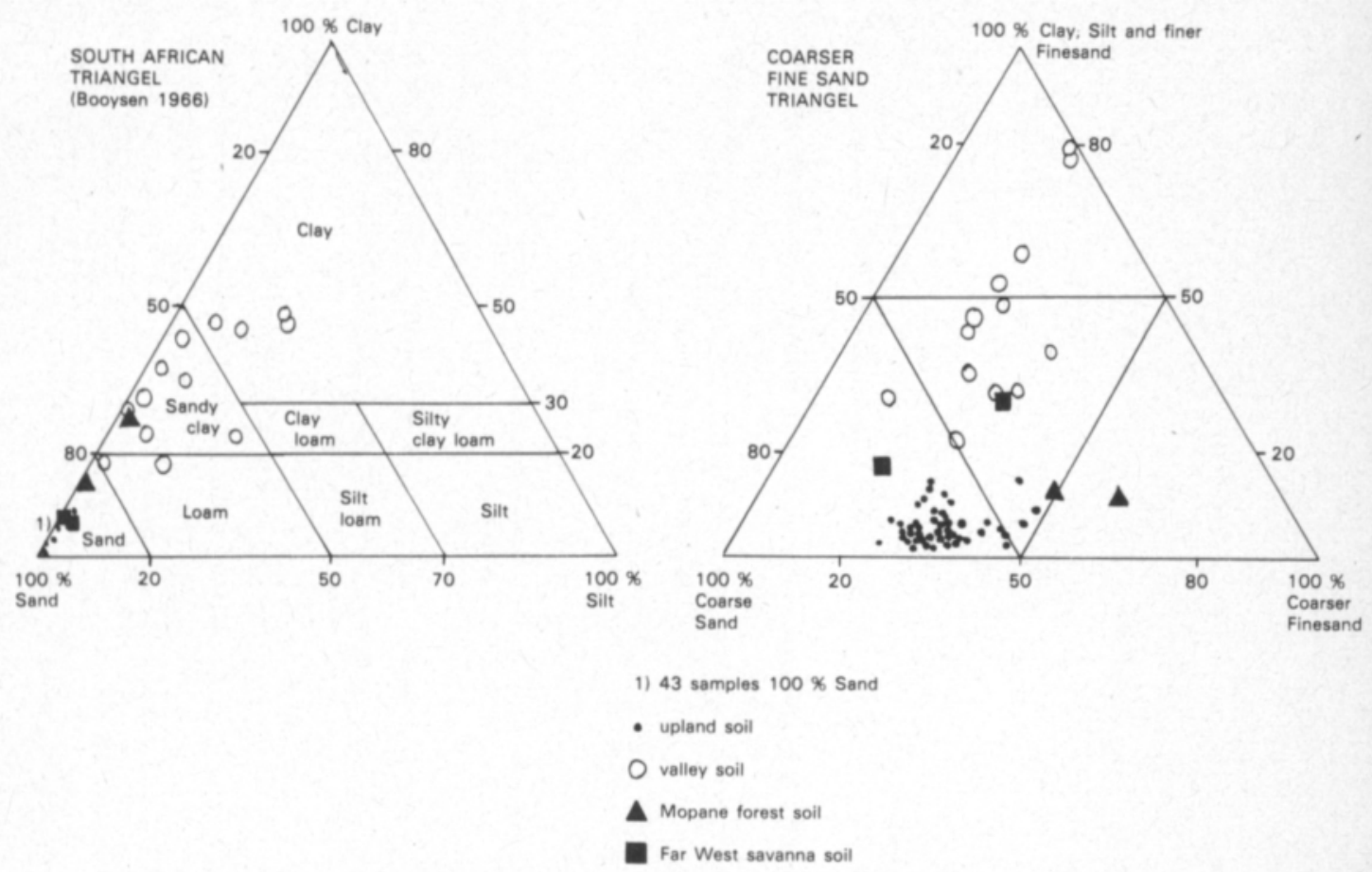

Fig. 6. Distribution of Ovambo. - Kavango soils in two different texture triangels.

In comparison of eastern and western soils and some special formations (Fig. 7) the sorting out of the particle sizes seams to have been stronger in the East than in the West.

\subsection{Soil organic matter}

Humus content determined in topsoils from 72 sites are quite low (Table 2). In high soils the humus contens are always less than $1 \%$ and differences about $0,5 \%$. In valley soils, the percentages are less than $5 \%$ and the differences are obvious, for the valley may be quite plantless or covered with different amounts and kinds of plants. The highest humus percentage $(0.91)$ in cultivated uplands was determined at the Nkongo mission station. The $0.80 \%$ is from a teacher's field in Ogongo. The

Table 2. Humus content of different soils in average.

\begin{tabular}{lclcl}
\hline & Samples & $\begin{array}{l}\text { Upland soils } \\
\text { Humus \% } \\
\text { average (low-high) }\end{array}$ & Samples & $\begin{array}{l}\text { Valley soils } \\
\text { Humus \% } \\
\text { average (low-high) }\end{array}$ \\
\hline $\begin{array}{l}\text { Cultivated } \\
\text { Owambo }\end{array}$ & 17 & $0.42(0.17-0.91)$ & 4 & $1.59(0.98-3.40)$ \\
$\quad$ Kawango & 6 & $0.44(0.28-0.57)$ & 1 & 0.86 \\
$\begin{array}{l}\text { Virgin } \\
\text { Owambo }\end{array}$ & 21 & $0.45(0.28-0.71)$ & 13 & $1.11(0.90-3.90)$ \\
Kawango & 7 & $0.53(0.30-0.65)$ & 3 & $2.22(0.80-4.05)$ \\
\hline
\end{tabular}



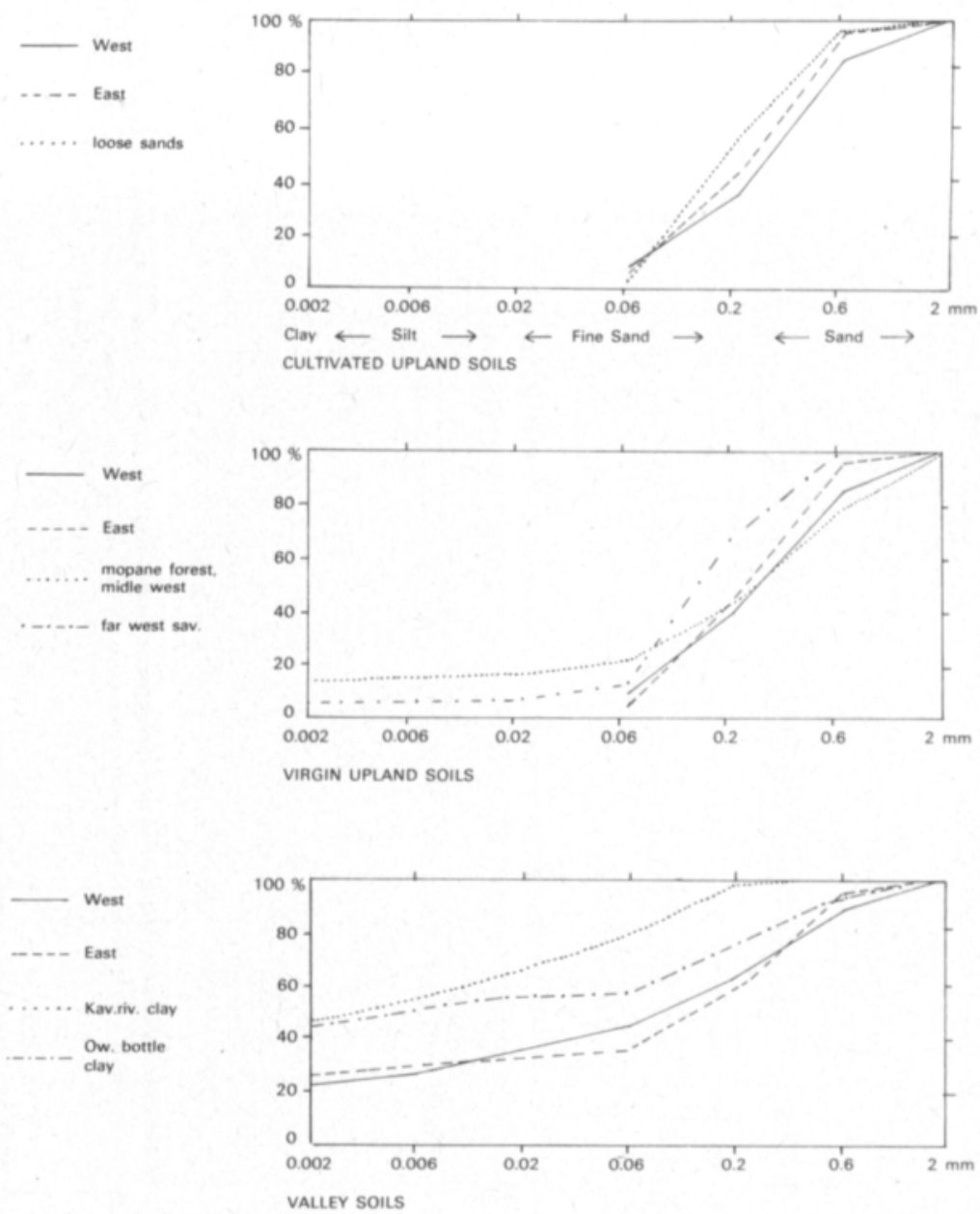

Fig. 7. Some average particle size distributions.

virgin upland soils contain slightly more humus than the cultivated soils. There was no difference however in the humus content between the forest and the grassland types of the virgin soils.

Nitrogen content, often connected closely with the amounts of soil organic matters, were also determined in South West Africa. They were found sufficient for gardening purposes only in 5 of 32 valley soil samples, but not in the 82 upland samples.

\subsection{Soil reaction}

The soil reaction appeared, on average, to be near neutral (Table 3 and Fig. 8). The $\mathrm{pH}$ values were in Kawango, where there is higher rainfall than elsewhere, a little lower in uplands and river, but higher in valleys. The same is slightly observable in Uukuanyama soils when compared with Ondonga and virgin west soils. The low $\mathrm{pH}$ values in western cultivated upland surfaces are exceptional and 
Table 3. Average soil $\mathrm{pH}$ and specific conductivity $\left(10 \times \mathrm{mmho} / \mathrm{cm} 20^{\circ} \mathrm{C}\right)$.

\begin{tabular}{|c|c|c|c|c|c|c|c|}
\hline \multirow{3}{*}{ Terrain type } & \multirow{3}{*}{ Samples } & \multirow{2}{*}{\multicolumn{3}{|c|}{$\mathrm{pH}$}} & \multicolumn{2}{|c|}{ Specific conductivity } & \multirow{3}{*}{$\begin{array}{c}40-60 \mathrm{~cm} \\
3\end{array}$} \\
\hline & & & & & & & \\
\hline & & 1 & 2 & 3 & 1 & 2 & \\
\hline \multicolumn{8}{|l|}{$\begin{array}{l}\text { Upland soils: } \\
\text { cultivated }\end{array}$} \\
\hline west & 10 & 6.33 & 7.00 & 7.50 & 0.59 & 0.71 & 1.47 \\
\hline Ondonga & 6 & 7.29 & 7.16 & 7.26 & 0.73 & 0.63 & 0.65 \\
\hline Uukuanyama & 7 & 7.09 & 7.10 & 7.07 & 0.66 & 0.55 & 0.78 \\
\hline Kawango & 5 & 6.33 & 6.36 & 6.39 & 1.80 & 0.49 & 0.49 \\
\hline \multicolumn{8}{|l|}{ virgin } \\
\hline west mopane forest & 4 & 7.06 & 7.42 & 7.67 & 7.40 & 13.06 & 19.30 \\
\hline west, others & 6 & 6.57 & 6.54 & 6.40 & 0.62 & 0.68 & 1.13 \\
\hline Ondonga & 6 & 6.61 & 6.97 & 7.22 & 0.61 & 0.79 & 1.66 \\
\hline Uukuanyama & 4 & 6.35 & 6.17 & 6.39 & 0.49 & 0.49 & 0.49 \\
\hline Kawango & 5 & 6.35 & 5.93 & 5.92 & 1.47 & 1.56 & 0.86 \\
\hline Deep loose sands & 4 & 6.27 & 5.92 & 6.25 & 0.49 & 0.49 & 0.49 \\
\hline \multicolumn{8}{|l|}{ Valley soils: } \\
\hline \multicolumn{8}{|l|}{ cultivated } \\
\hline Uukuanyama & 4 & 7.24 & 7.62 & 7.71 & 0.98 & 1.25 & 1.21 \\
\hline Kawango $^{1}$ & 2 & 6.87 & 6.77 & 6.60 & 1.33 & 1.06 & 0.88 \\
\hline \multicolumn{8}{|l|}{ virgin } \\
\hline west & 6 & 7.13 & 7.47 & 7.79 & 6.52 & 5.88 & 3.13 \\
\hline Ondonga & 5 & 7.08 & 7.44 & 7.68 & 2.79 & 2.79 & 3.73 \\
\hline grassland & 2 & 9.40 & 9.47 & 9.20 & 14.63 & 20.46 & 6.60 \\
\hline Uukuanyama $^{1}$ & 2 & 6.95 & 6.98 & 7.05 & 0.93 & 0.50 & 0.49 \\
\hline Kawango & 2 & 7.12 & 7.90 & 7.97 & 2.35 & 1.00 & 0.98 \\
\hline
\end{tabular}

1 temporary river
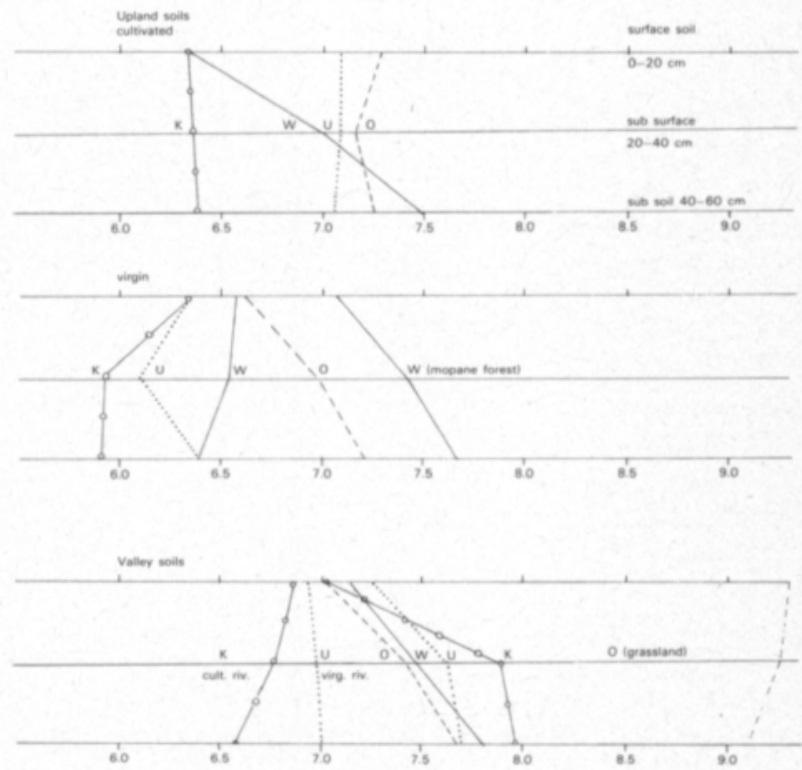

Fig. 8. Average soil $\mathrm{pH}$ in various soil groups and districts.

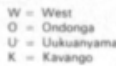


may be connected with their low calcium and high phosphorus contents and very slight height differences. The loose sand soils have a slightly lower $\mathrm{pH}$, because rainwater is absorbed more easily than in other uplands. Subsoils seem to turn to weak alkaline, especially in the valleys and low western soils. The highest $\mathrm{pH}$ values $(\mathrm{pH} 9.85)$ were determined in the Ondonga low grasslands, close to Etosha and in the deep valley soil of Oshigambo. The lowest $\mathrm{pH}(4.90)$ was in the Ondonga grasslands in dune top formation and in the Oshango deep, loose sands of the forest savanna.

Tables 5 and 6 show that cultivated fields registered a reaction between 5 and 7.50. Virgin soils had greater variability and valley soils greater alkalinity. The same variabilities have been stated in samples analysed in South West Africa.

\subsection{Specific conductivity}

Specific conductivities in millimho/ $\mathrm{cm} / 20^{\circ} \mathrm{C}$ usually proved to be too low (Tables 3, 5 and 6). But values, that are too high have also been found in virgin and valley soils. In particular, a too high brack content has been stated in plantless "Oshana" in Tsandi.

Table 4. Average nutrient content in soils according to terrain types and districts

\begin{tabular}{|c|c|c|c|c|c|c|c|c|c|c|}
\hline \multirow{4}{*}{$\begin{array}{l}\text { Terrain types } \\
\text { and district }\end{array}$} & \multirow{4}{*}{ Samples } & \multicolumn{9}{|c|}{ Ammonium acetate extractable $(\mathrm{pH} 4.65)$} \\
\hline & & \multicolumn{3}{|c|}{$\mathrm{Ca} \mathrm{mg} / \mathrm{l}$} & \multicolumn{3}{|c|}{$\mathrm{K} \mathrm{mg} / \mathrm{l}$} & \multicolumn{3}{|c|}{$\mathrm{P} \mathrm{mg} / \mathrm{l}$} \\
\hline & & 1 & 2 & 3 & 1 & 2 & 3 & 1 & 2 & 3 \\
\hline & & $\begin{array}{c}\text { surface } \\
0-20 \mathrm{~cm}\end{array}$ & $\begin{array}{c}\text { sub- } \\
\text { surface } \\
20-40 \\
\mathrm{~cm}\end{array}$ & $\begin{array}{c}\text { subsoil } \\
40-60 \\
\mathrm{~cm}\end{array}$ & & & & & & \\
\hline \multirow{2}{*}{\multicolumn{11}{|c|}{$\begin{array}{l}\text { Upland soils: } \\
\text { cultivated }\end{array}$}} \\
\hline & & & & & & & & & & \\
\hline west & 10 & 417 & 617 & 947 & 106 & 122 & 173 & 5.9 & 5.9 & 4.8 \\
\hline Ondonga & 6 & 762 & 800 & 975 & 116 & 146 & 167 & 5.9 & 3.9 & 3.4 \\
\hline Uukuanyama & 7 & 951 & 1204 & 2607 & 133 & 101 & 99 & 3.1 & 0.6 & 0.7 \\
\hline Kawango & 5 & 355 & 545 & 565 & 72 & 71 & 63 & 3.4 & 1.1 & 0.6 \\
\hline \multicolumn{11}{|l|}{ virgin } \\
\hline west mopane forest & 4 & 475 & 820 & 750 & 158 & 192 & 267 & 0.8 & 1.1 & 0.7 \\
\hline west, others & 6 & 2850 & 2779 & 967 & 232 & 218 & 197 & 1.1 & 1.2 & 0.7 \\
\hline Ondonga & 6 & 625 & 4121 & 12121 & 110 & 109 & 142 & 1.2 & 1.3 & 2.2 \\
\hline Uukuanyama & 4 & 331 & 275 & 219 & 51 & 24 & 21 & 1.8 & 0.8 & 0.6 \\
\hline Kawango’ & 5 & 508 & 310 & 283 & 53 & 41 & 3 & 2.1 & 1.0 & 0.7 \\
\hline Deep loose sands & 4 & 150 & 83 & 67 & 32 & 13 & 15 & 1.8 & 1.1 & 1.1 \\
\hline \multicolumn{11}{|l|}{ Valley soils: } \\
\hline \multicolumn{11}{|l|}{ cultivated } \\
\hline Uukuanyama & 4 & 17981 & 42831 & 53106 & 424 & 305 & 255 & 11.1 & 7.8 & 8.4 \\
\hline Kawango & 2 & 1300 & 1363 & 1687 & 280 & 72 & 42 & 5.7 & 1.9 & 1.1 \\
\hline \multicolumn{11}{|l|}{ virgin } \\
\hline west & 6 & 3087 & 3429 & 11025 & 676 & 508 & 387 & 1.1 & 3.0 & 3.8 \\
\hline Ondonga & 5 & 4521 & 4550 & 4500 & 634 & 586 & 541 & 6.9 & 4.4 & 3.8 \\
\hline grassland & 2 & 5050 & 8050 & 100 & 315 & 340 & 150 & 2.8 & 3.2 & 1.1 \\
\hline Uukuanyama ${ }^{1}$ & 2 & 1550 & 2450 & 3850 & 92 & 95 & 105 & 0.3 & 0.4 & 0.2 \\
\hline Kawango & 2 & 14687 & 13995 & 5150 & 445 & 185 & 165 & 9.9 & 4.3 & 3.2 \\
\hline
\end{tabular}

\footnotetext{
1 temporary river
} 


\subsection{Macronutrients}

\subsubsection{Calcium}

Deposits of calcium in Owambo and Kawango are quite apparent in some profiles. White lime layers have been found in many places, in various depths, and in various forms. Just under the topsoil in Omangundu, there are loose lime layers and in Engela, concrete lime layers. There are lime concrete under the subsurface in Nkongo and more than $10 \mathrm{~m}$ deep under sand layers in Ombafi. In Uusathima, water has been extracted from lime concrete layers. Lime layers seem to be more common near valleys (such as "iihenene") and at river banks, such as those found in Oshigambo, Onguediva and east of Mupini in the Kawango area. The exchangeable calcium amounts in the analysed soils are variable. Generally (Tables 4-6 and Fig. 9 ), the cultivated soil surfaces have a low calcium content, the virgin soil surfaces seem to have still less calcium and the loose sands least of all. Many valley soils are rich in calsium however, for example, some cultivated valleys in the Uukuanyama have very high $\mathrm{Ca}$-contents. This may even be the reason for the cultivability of those soils. It seems (Table 6), that cultivated fields usually have somewhat higher $\mathrm{Ca}$-contents than virgin upland soils. Some virgin soil samples with high $\mathrm{Ca}$-contents were taken from the above lime profiles, from low grasslands in Southern Ondonga and close to one plantless valley in the west. Thus, all of them seem to be exceptional sites.

Table 5. Interpretation table of soil testing results for mineral soils (KURKI, LAKANEN et al. 1965).

\begin{tabular}{llllc}
\hline Fertility class & & $\begin{array}{l}\mathrm{pH} \\
\text { Coarse }\end{array}$ & $\begin{array}{l}\text { Clay } \\
\text { soils }\end{array}$ & $\begin{array}{c}\text { Specific conductivity } \\
10 \times \text { millimho/cm }\left(20^{\circ} \mathrm{C}\right)\end{array}$ \\
\hline Too high to high & 7 & $7.4<$ & $7.4<$ & 10 \\
Very good & 6 & $6.6-7.3$ & $6.6-7.3$ & \\
Good & 5 & $6.2-6.5$ & $6.2-6.5$ & 4 \\
Satisfactory & 4 & $5.8-6.1$ & $5.8-6.1$ & 2 \\
Rather low & 3 & $5.4-5.7$ & $5.4-5.7$ & \\
Low & 2 & $5.0-5.3$ & $5.0-5.3$ & \\
Very low & 1 & $5.0>$ & $5.0>$ & \\
\hline
\end{tabular}

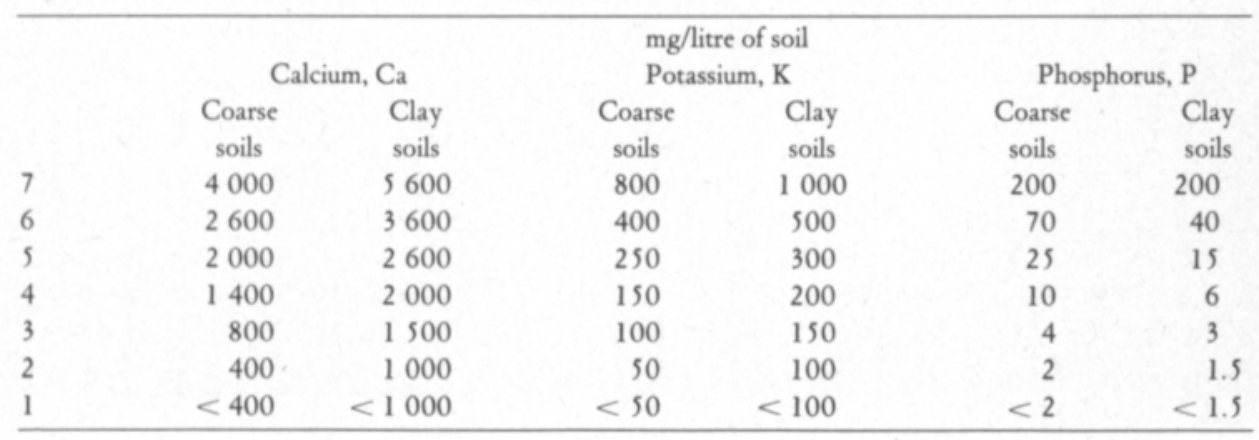


Table 6. Distribution of soil samples in fertility classes.

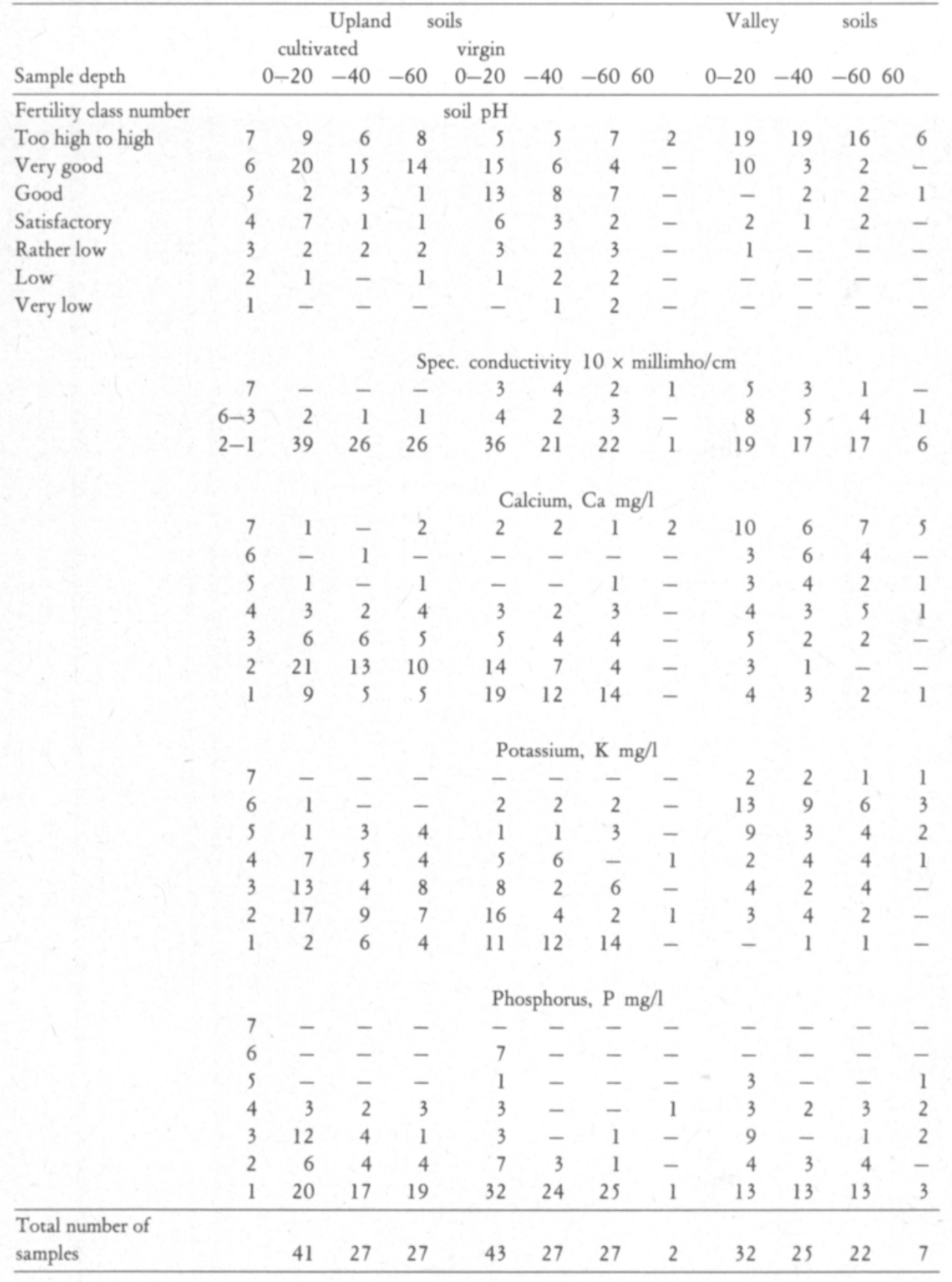

\subsubsection{Potassium}

Exchangeable K-contents (Tables 4-6 and Fig. 10) are generally low. In valley soils, the $\mathrm{K}$-contents of the subsoils are lower than those on the surface. Otherwise, the potassium-contents of the valley soils seem to be very good for plant growth, especially, when it's very low in the virgin uplands and cultivated fields. Some very 

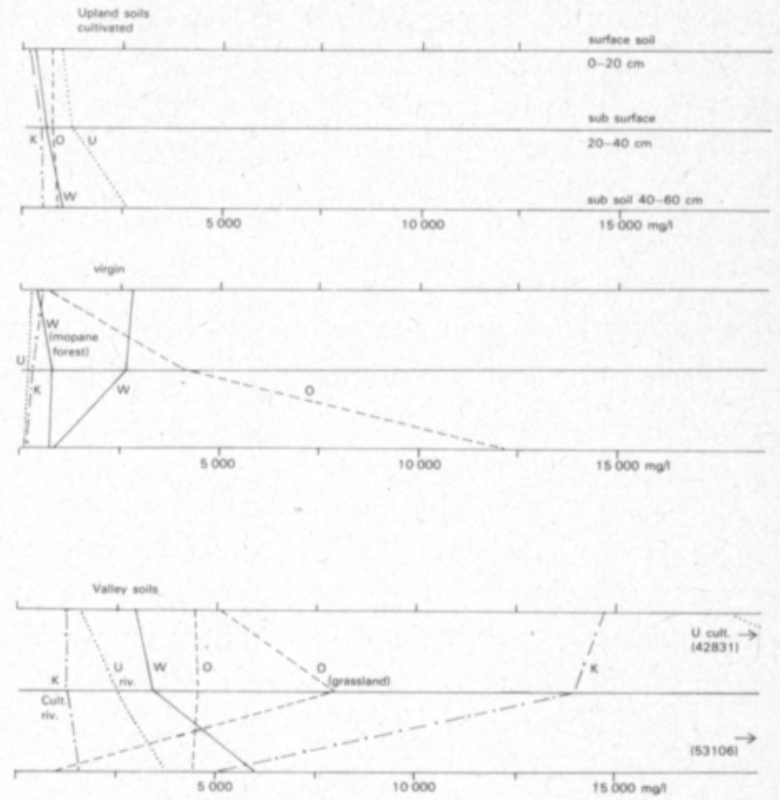

Fig. 9. Exchangeable Calsium (Ca).

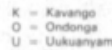

$\mathrm{u}=$ Uuduarivame
$\mathrm{w}=$ West
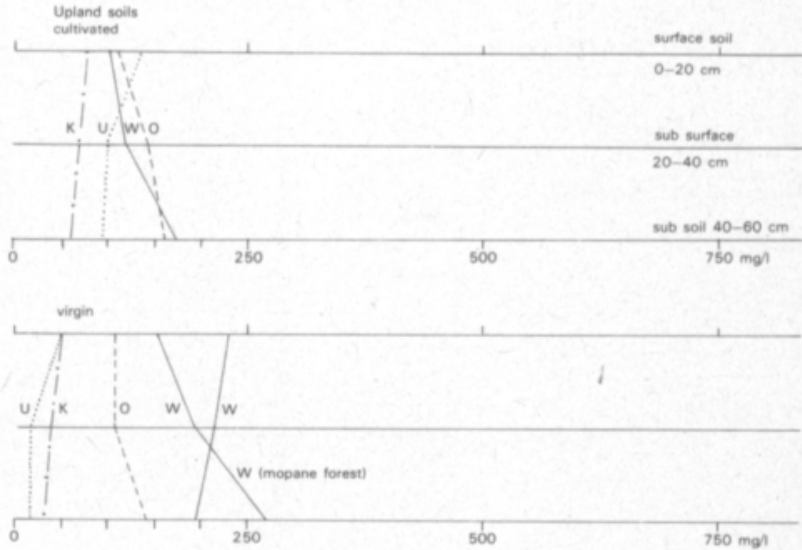

Fig. 10. Exchangeable Potassium (K).

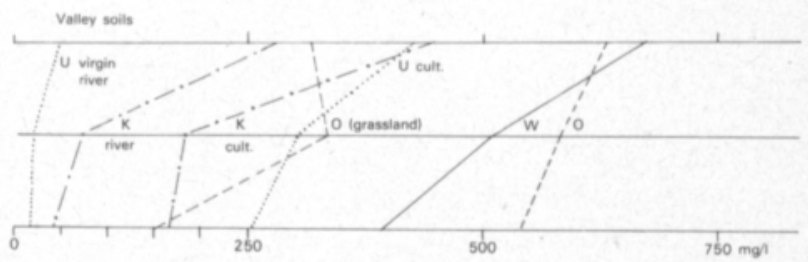

$K=$ Kavango
$0=$ Ondonga
Y

$u=$ Uukuanyama 
high $\mathrm{pH}$ values in the valleys, seem to be caused by sodium carbonate. On some valley soils in the south, on the Etosha district, salt (sodium chloride) has been found as white layers above the surface, mixed with redish potassium salt. Very high $\mathrm{K}$ contents prevent plants from using the soils magnesium, but there are only a few overhigh $\mathrm{K}$-contents which must be remembered when fertilizers are being used on sand soils.

Potassium-contents analysed in South West Africa were found to be high enough for plant growth in 21 of 32 valley soils and in 11 of 82 upland soils. This is similar to test results done with the Finnish method.

\subsubsection{Phosphorus}

Ammonium acetate extractable phosphorus amounts ( $\mathrm{pH} 4.65)$ are very low (Tables 4-6 and Fig. 11). The same tendency is observable, as with calcium and potassium, which show the trend of being more in cultivated, less in virgin and most in valley soils. Some cultivated Ondonga and west soils contain more phosphorus than others and some valley surface soils more than their subsoils.

According to the South West African analyses, 5 of 32 valley and 11 of 82 upland soils contain enough phosphorus for plant growth. There is a slight divergence from Finnish results, which show a slightly better phosphorus situation in the valleys than other soils. However, generally, a shortage of phosphorus is obivious in all soil profiles.

\subsubsection{Magnesium}

The magnesium (soluble in ammonium acetate $\mathrm{pH} 4.65$, Table 7) content is too low for plant growth in 11 of 59 samples analysed $(\mathrm{Mg} 80 \mathrm{mg} / \mathrm{l}$ of soil), especially
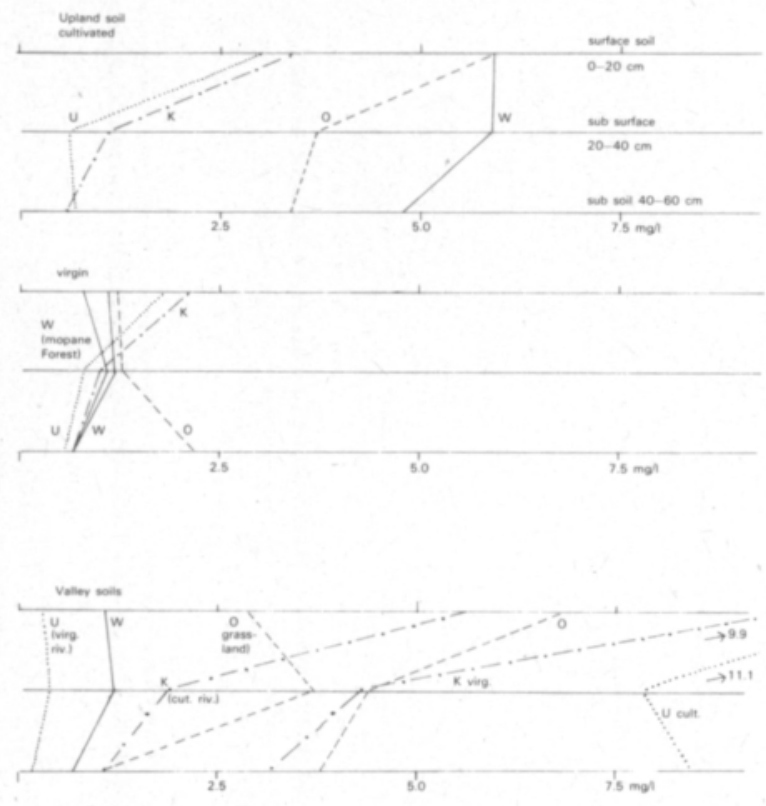

Fig. 11. Readily soluble phosphorus (P). 
Table 7. Average ammonium acetate ( $\mathrm{pH} 4.65)$ extractable $\mathrm{Mg}, \mathrm{Mn}, \mathrm{Fe}$ and $\mathrm{Zn}$ contents of different soils ( $\mathrm{mg} /$ litre of soil).

\begin{tabular}{|c|c|c|c|c|c|}
\hline \multirow[t]{2}{*}{ Soils } & \multicolumn{2}{|c|}{ cultivated } & \multicolumn{3}{|c|}{ virgin } \\
\hline & upland & valley & upland & forest & valley \\
\hline samples & 20 & 5 & 10 & 11 & 10 \\
\hline plant nutrient & \multicolumn{4}{|c|}{$\mathrm{mg} /$ litre of soil } & \\
\hline Magnesium, $\mathrm{Mg} \ldots \ldots \ldots \ldots$ & 138 & 928 & 311 & 166 & 531 \\
\hline Manganese, $\mathrm{Mn}$............ & 23 & 41 & 23 & 24 & 15 \\
\hline Iron, $\mathrm{Fe} \ldots \ldots \ldots \ldots \ldots \ldots$ & 1.6 & 2.6 & 3.2 & 2.3 & 4.9 \\
\hline Zinc, $Z_{n} \quad \ldots \ldots \ldots \ldots \ldots$ & 0.23 & 0.23 & 0.20 & 0.22 & 0.20 \\
\hline
\end{tabular}

in high soils. It is rather low in all the upland soils. All of the valley soils analysed contain some $\mathrm{Mg}$, but nearly half contain considerable amounts. Magnesium deficiencies with heavy potassium fertilizing may cause high potassium/magnesium relations in plants with diseases in livestock and possibly humans as a result. In addition the imbalances in macronutrient relations may cause disturbances in micronutrient uptake.

\subsection{Micronutrients}

\subsubsection{Manganese}

The recorded amounts of manganese $\left(\mathrm{NH}_{4}\right.$-acetate soluble in $\mathrm{pH} 4.65$, Table 7$)$ are not totally reliable, since the samples were analysed during three years, instead of less than 3 months. Furthermore, the amounts were quite low $(\mathrm{Mn} 9 \mathrm{mg} / \mathrm{l}$ soil) in 8 samples and insufficient in 25 of 59 samples. Only two valley and 8 upland soils have soluble manganese contents, which are clearly sufficient for plant growth $(\mathrm{Mn}$ $38 \mathrm{mg} / \mathrm{l}$ of soil). It has been suggested that manganese deficiency together with other deficiencies may increase the susceptibility to cancer and other deseases in man and livestock (MARJANEN and SOINI 1972). Total manganese contents (Table 8) are especially in valley soils quite much higher than the soluble ones.

Table 8. Average total element content in different soils $(\mathrm{mg} / \mathrm{kg}$ dry soil).

\begin{tabular}{|c|c|c|c|c|c|}
\hline \multirow[t]{2}{*}{ Soils } & \multicolumn{2}{|c|}{ cultivated } & \multicolumn{3}{|c|}{ virgin } \\
\hline & upland & valley & upland & forest & valley \\
\hline samples & 17 & 2 & 6 & 4 & $6(2)$ \\
\hline trace element $\ldots \ldots \ldots \ldots \ldots$ & & & $\mathrm{mg} / \mathrm{kg}$ & & \\
\hline Cobalt, Co .............. & - & 8.7 & - & - & 4.9 \\
\hline Copper, $\mathrm{Cu} \ldots \ldots \ldots \ldots \ldots$ & - & 19.0 & - & - & 10.7 \\
\hline Manganese, $\mathrm{Mn}$.......... & 32.9 & 333.5 & 21.8 & 20.0 & 87.8 \\
\hline Molybdenum, Mo .......... & - & - & - & - & - \\
\hline Nickel, Ni ............. & 0.6 & 16.4 & - & - & 18.0 \\
\hline Lead, $\mathrm{Pb} \ldots \ldots \ldots \ldots \ldots \ldots$ & 12.9 & 7.2 & 16.6 & 9.7 & 13.4 \\
\hline Strontium, $\mathbf{S r} \ldots \ldots \ldots \ldots$ & - & 290.0 & - & - & $(85.5)$ \\
\hline Vanadium, $\mathbf{V} \ldots \ldots \ldots \ldots$ & 1.9 & 32.0 & - & 2.8 & 26.8 \\
\hline Zinc, $\mathrm{Zn} \quad \ldots \ldots \ldots \ldots \ldots \ldots$ & - & 28.0 & - & - & 4.7 \\
\hline Tin, Sn $\ldots \ldots \ldots \ldots \ldots \ldots$ & - & - & 0.42 & - & $(1.2)$ \\
\hline
\end{tabular}




\subsubsection{Iron and zinc}

Iron and zinc contents $\left(\mathrm{NH}_{4}\right.$-acetate extractable in $\left.\mathrm{pH} 4.65\right)$ seem to be rather low (Table 7).

\subsubsection{Other trace element levels}

Some total trace element levels $(\mathrm{mg} / \mathrm{kg}$ dry soil Table 8$)$ were determined from 46 surface soil samples, 17 cultivated uplands, 8 valley soils, two of which were cultivated. All upland soils seem to be nearly pure quartz sand, with very little $\mathrm{Mn}$ and $\mathrm{Pb}$ were found in the analysed samples. Generally the valley soils micronutrient content was low with small amounts of $\mathrm{Co}, \mathrm{Cu}, \mathrm{Ni}, \mathrm{V}$ and some higher contents of $\mathrm{Mn}$ occuring (however $\mathrm{Mn}$ may not all be easily available for plants in alkaline valley soils). $\mathrm{Sr}, \mathrm{Zn}$ and $\mathrm{Sn}$ were each found in 2-3 samples, however Mo was not found in any of the analysed samples. Selenium and sulphur were not analysed. Alkaline soils may contain selenium and some plants can absorb it until toxity, however pure sandy soils are usually poor in selenium and selenium is one essentisl nutrient, which may even be leached out from slightly acid uplands. Boron was not analysed, but there may be shortages of it, since root crops did not grow well. According to the analyses (Table 8), there seems to be a total lack of molybdenum which may cause a situation of toxity if abundant nitrate fertilizers are used. $\mathrm{Co}, \mathrm{Cu}$ and $\mathrm{Zn}$ were found in valley soils, but not in the usual cultivated levels, therefore, it can be suggested that many plants which have micronutrient requirements were consumed by cattle to a greater extent when occuring in the valleys and parts of many valley plants were used as food additives for people.

4. Observations and questions concerning farming in the 1965-1970 Owambo and Kawango

Associated with the soil studies above, plants were collected to identify the Owambo-Kawango flora and probable soil indicator plants. Two fencing trials were made on an overgrazed veld and local fertilizing trials were organized. Some machines, shade and dam materials were used in different places, seed dressing was used for native seeds and new seeds were used in trials. These trials, however were not sufficient for the collection of reliable results. Consequently, all possible observations are presented with several questions concerning farming in the area.

\subsection{Water supply}

\subsubsection{Storage and irrigation}

Watering schemes, dams, boreholes, pumps and experiment stations are within the South West African government program. Pumps are maintained in connection with the canal scheme from the Kunene river. Apart from the old experiment station 
at Oshakati, some irrigated experiment areas have been under cultivation for about fifteen years in the Kawango area and a new, large experiment farm with irrigation facilities and pasture camps on the canal ought to be developed in connection with the agricultural college in Ogongo, in mid-west Owambo. The Roman Catholic Mission has irrigated gardens in the Kawango area. In Owambo they grow flowers and vegetables with shading and irrigating from deepened water pools.

The Finnish missionaries have made small private gardening efforts depending solely on individual interest and energy. However some previously irrigated sites have become difficult to start up again, although by irrigating with water from their own wells, some natives seem to have enlarged their vegetable and fruit gardening for marketing. Usually, most establishment difficulties stem from the shortage of drinking water. The canal water is not enough for the whole of Owambo and none of the other common water sources are made for irrigation. Therefore improvement of the water supply is most important. Existing dams should be protected against erosion and small, cheap pumps can be used to pump water from ordinary deep holes and from the oshanas for storage, although even without covering against evaporation, water will stay longer in a small deep dam than in a large shallow oshana. Rain water for home use can be ensured through the increasing use of iron sheet roofs, provided that storage is organized. Plastic dam method may still need further development for water storage purposes.

Owing to the neutral to weak alkaline sandy soils and high evaporation, there is a danger of salt accumulation in the soil surface and many other questions will occur. Will it be better to irrigate during the rainy season at dry periods only or will abundant irrigation at long intervals of varying amounts at shorter intervals be good enough? Will drainage systems for oshanas and limited irrigation with micropore watering pipes close to the plants for uplands be profitable? In any case same kind of undersurface watering system could be organized at least for fruit trees. These questions are studied in some other arid regions like in Negev in Israel.

\subsubsection{Prevention of run off}

The rainfall is sufficient for dry cultivation, but run off during heavy thunderstorms (average 40-50 rainy days) and lack of humus, makes shortage of water in high sand soil worse than the actual shortage of rainfall. Dry periods are very common between the first rains and they can cause difficulties even though there is no question of drought. Thus, there are opportunities for an individual farmer or for groups of farmers to organize more reliable water supplies for their fields by means of simple techniques.

It is the first heavy rain of the season which causes run off from the hard trampled fields and although ploughing is common, it is done in any direction, and after the first rain, instead of before the rain and always across the slopes. After the dry season, the animals are weak and the soil is hard. Soil preparation after the harvest however has been a taboo since Owambo people believe that ploughing then weakens the animals and causes them to die before the end of the dry season, but this will be avoided by extra food for ploughing animals. To supply extra machinery seems unnecessary for the present agricultural regime before outside markets for the crops. The harrowing as weed control happens usually at quite right time but the old 


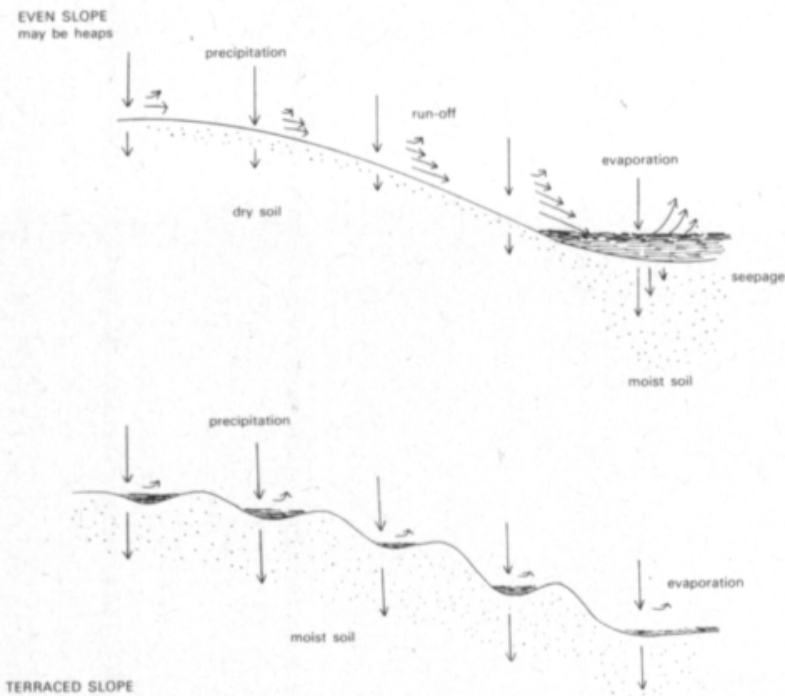

with ridges and ties

Fig. 12. Run-off on different slope surfa-

custom of creating high heaps of soil for the plants causes water run off between the heaps. These heaps are made higher near the valleys where they may be important in contributing towards brackish water or overlodging of soils. Instead of heaps effective walls or ridges ought to be made all along the slope (Fig. 12.,WEBSTER et al. 1966, SYMMONS 1968). They could be created in the same way as the heaps higher near the valleys but they will also prevent run off. Soil analyses taken from the heaps suggested no exceptional danger of salt build up if ploughing is deepened, provided that this is done gradually. Ploughing on ridges however, will not alone be sufficient against run off. Ties ought to be made between ridges with soil barriers in furrows at regular intervals $(1.5-3.5 \mathrm{~m})$ necessitating a number of basins roughly on the contour and across the slopes (BROWN 1963). When preceding ties and ridges are strong enough, they will prevent run off, even if ploughing is done after the first rains of the following season. Dry cultivation with minimum tillage or alternate year sowing could be tested in trials, but annual preparation of soil would have to include after harvest harrowing.

\subsubsection{Prevention of seepage}

To maintain and increase humus contents in sandy soil can contribute significantly towards the maintainance of soil water levels. However, to increase humus in soil is not easy. Agricultural practices in the region have used farmyard manure both as fertilizer and as source of humus. The amounts of manure have been low since grazing is often done far from the fields. Supplementary feeding for some animals in restricted areas will increase the amounts of manure and when crop residues have been used in farmyards to create extra humus, good results have been achieved. All organic material in fact should be saved, sewagand even latrine compost, however, ploughing-in crop residues is the most usual way in a humus campaign but must be timed so that ploughing is early enough before the rainy 
season or after the harvest. Another method of ploughing crop residues is a modern mulch tillage (McALISTER 1962) or minimum tillage, covering the crop residues with soil between the furrows. Such a system may be profitable in Owambo, but suitable times, implements and planting usage should first be tested.

Both run off and seepage mean a loss of water for the cultivated plants. But it is important to remember that in Owambo seepage is not just water loss. Seepage implies, an increasing amount of good underground water. Run off means a real loss of valuable water through increasing evaporation and the quantity of highly brackish underground water. The surface soils existing in oshanas are usually cemented with clay and mud and do not allow water to be absorbed quickly and evaporation from an open water surface is always greater than from any soil.

Crop rotation can provide means of soil improvement, thereby reducing the severity of run off and seepage. The ancient system of crop rotation meant moving the whole house every third year. This is no longer common for clay and brick houses are being built in increasing numbers, however the combination of mixed sowing and the disuse of the weak parts of the field, together with modern crop rotation is increasing. Lay fields are elsewhere used in crop rotation and lucerne is a suitable lay plant for irrigated fields, but which lay and fodder plants could be dry cultivated in Owambo? Leguminous plants, some Sorghum, Pennistum and Eragrostis species can be used for silage and hay and some crop rotations may be possible and profitable with these. Sunflower and cotton will grow well in Owambo and Kawango soils.

\subsubsection{Limiting evaporation}

The fields are usually surrounded by brushwood with shade or fruit trees left inside, but there are many very open places where planted wind-breakers would be desirable (not too dense, WEBSTER et al. 1966). Some milkweed species for example are easy to plant and without any treatment. It would be better however, if some other valuable trees were used for the same purpose, for example Acacia albida (ana tree), as a fodder producer or a gumproducing Acacia. Various shelters seem to be in common use in advenced cultivation in the south-west. In trials, a $50 \%$ shade was good for seedlings but greater shades increased fungus diseases. Sowing a little deeper with planters, gives a better growth than shallow hand sowing. On the slopes, rows should run across only but on quite level soils, rows from south to north will give more shade to the soil between the rows and consequently save moisture. In row cultivation, harrowing between the rows will be easier and faster at the right time, better implements can be used and the hoe used only in closeup work with plants. In addition, unnecessary transpiration can be prevented in spite of weed harrowing, even with short-growing varieties like some new hybrid sorghums.

Grass mulch will be helpful in many cases, provided that enough grass has been moved during the rainy season. Peat was found to be very good for growing seedlings or if wood humus preparation can be made easily, it will be profitable because useless bushes are abundant and merely take up grazing land (cf. WEBSTER et al. 1966). Also, wood work production is increasing and sawdust will thus become obtainable. One gardener in a town nearby (Tsumeb) used sawdust layers on nursery soils with good results. 
Container planting, for example paper pots, will be particularly helpful in the beginning of the difficult growing season making the planting period easy for both plants and planters.

\subsection{Plant nutrient supply}

\subsubsection{Organic fertilizers}

Organic fertilizers are important in sand soils which are poor in humus and plant nutrients. The ferroting process is quite rapid (less than $1 / 2$ year) with compost and ploughing of organic matter, provided there is enough moisture. Usually however, there is a shortage of water. A sanitary custom of making deep holes in the sand soils for latrines may pollute the underground water, especially when abundant washing powders are used. For this reason it will be very important to construct compost latrines, where organic matter can prevent water from seeping and microbes can use both water and nutrients from the sewage. Mr. Karhumäki at Onandjowe hospital has conducted a trial on irrigating trees directly from the sewage, through underground watering pipes. Compost may be supplemented with artificial fertilizers and suitable microelement mixtures (basic slag, if nothing else). If these are not obtainable, there are leaves and residues from trees, which receive their nutrients from deep layers and thus, may contain a considerable portion of all the necessary nutrients.

Farmyard manure has been used on cultivated fields, since ploughing first came into use. The farmyards are open enclosures with sometimes a shade tree nearby. In order to preserve all the plant nutrients in the manure, shades or shelters are necessary and they ought to be made with a hardened or cemented basement for preserving the urine wastes. Green manure usually needs a slightly longer rainy season if it is applied in the same year as the main crop. In the Owambo-Kawango area it is suitable, for example, where fields can be left to fallow or are involved in crop rotation. On the sandy soil especially crop residues or other organic matters ought to be used to form humus. One profitable way of spreading the manure will be using the farmyard as a pasture camp in crop rotation. The old custom of spreading the manure in September, "when there is time enough" and ploughing it before the first rains in November-January wastes manure since the winds in OctoberNovember may even totally remove it from the fields. This system can be changed by introducing "water saving" ploughing. The weather is rather cool for spreading the manure after the harvest. When threshing is made easier with new implements, for example, with co-operative machinery, it would leave time enough for manuring and ploughing, before the soils are too dry to plough. In usual ploughing in same crushing the crop residues will be needed. Mulch tillage, another way of ploughing in organic materials, must be adjusted to the local situation with making furrows and ridges across the slopes. It will even make possible to plough between the old furrows only after the first rains and it does not need crushing of crop residues so much. 


\subsubsection{Artificial fertilizers}

Artificial fertilizers have given some very good results in local trials, showing from one to fourfold yield increases, however, there are difficulties in their use on sandy soils since although fertilizer mixtures with high plant nutrient contents are easy to use and have low freight costs they usually contain macronutrients only and will rapidly cause a shortage of micronutrients, especially in sand soils. Stress is first seen in plants and later, cancer and other diseases may occur in humans and animals. Cancer is already a well-known disease in Owambo and therefore microelement fertilizers or other supplementing methods are mandatory, if higher yields are to be achieved with artificial macroelement fertilizers. A fertilizer with impurities such as basic slag (Thomas phosphate), can be of advantage since it contains many different micronutrients and is suitable for compost and weakly acidic soils, however, consultations will be necessary concerning freight costs.

\subsubsection{Soil improvements}

Soil improvements with agricultural lime or gypsum are possible on some muddy and brackish valley soils and lime can also be applied to acidic uplands. There are also some weakly acidic sand soils, which can be improved with alkaline fertilizers. In improving nearly pure sand soils, organic materials are needed, otherwise artificial supplements will cause an imbalance. It could be possible to use some of the country's own resources such as lime layers of the valley banks ("iihenene"), also, some valley soils contain considerable amounts of many nutrients, which are at a minimum in many cultivated fields (Tables 6,7 and 8). Studies of such soils should be continued and more trials should be made while their effects were found varying from improvement to toxic effects. Together with the need of many plant nutriets the main plant nutrient levels ought to be in balance, it means that all the nutrient levels should be on the same level on one field even if the level is different in different fields. Most of all there seems to be a need for increasing phosphorus gradually while more potassium and a little calcium on upland soils are needed. Investigation into the reserves of salts in Etoshapan ought to be studied.

\subsection{Soil conservation in the veldt}

There are clear signs of soil erosion, especially in middle Owambo, but also in every other district except in virgin forests. Overgrazing has caused bare spots and dry winds have blown the sand between less valuable plants, where it accumulates to miniature "heights" or "plateaus". The heavy rain takes small particles, humus and salts off the heights back to the gradually hardening and expanding open patches (iipale). Water has insufficient time to sink in on the heights and it becomes more difficult for it to sink in on the iipale. Thus, the water can only evaporate and run off into shallow oshanas and finally, to the Etosha salt pan. The amount of rainfall may still be the same, but less rain water will be absorbed, trees, people and animals continuously use underground water during the dry season with the groundwater level gradually sinking deeper resulting in the Etoshapan and further in the underground salt lake accumulating more and more saline run off water. Even on weakly-growing grassveldts, it will be profitable to plough some furrows across the 
slopes against run off, thus every individual farmer and the co-operative farmers of the districts, should begin to destroy emergent iipales and plough furrows on the intervening heights, in order to protect their country against increasing aridity. One trial was made by ploughing the iipale at Onandjokwe hospital and the results were promising. McGHIE (1979) in Australia has studied managing water-repellent soils, which seemed to be rather similar phenomenon with "iipale" formation.

Other signs of erosion are abundant; worthless plants, such as the "iisimba". (Pechuel-Loeshia babniziae) and short hard grasses instead of "ombindangolo" (Eragrostis sp.), a lack of valuable trees, rejected fields and useless bushes. All of these can be seen in various amounts and stages in different parts of the country. Ordinary methods for preventing soil erosion on pastures and cultivated fields are presented in many textbooks but practical application is often difficult. The above soil studies show, that Owambo and Kawango are mixed veldt types but owing to the old "livestock is money" system in these areas, organizing totally different types of livestock farming or agricultural reforms seem to be needed in prevention of soil erosion. However, it will be possible to organize tribal or local pasture camp systems or rotating rest camp fencings in co-operation with the local headmen. With some good examples reforms will be accepted by the people more easily and it may provide a basis for further developments. One trial was conducted to improve an overgrazed veldt in Oshigambo. A fence was built in early 1967 and nitrogen, phosphorus and potassium were given in the mixture 2:3:2 (22\%) $300 \mathrm{~kg} / \mathrm{ha}$. In the following rainy season, the fertilized squares already had Eragrostis as the principal established species. Hay was obtained from these squares in an average amount of c. $4000 \mathrm{~kg} / \mathrm{ha}$, while unfertilized squares retained the same short grass (Tragus sp), producing no hay. In the third year, the differences were still quite distinct. The unfertilized veldt produced only some Eragrostis, with Schmidtia and Aristida species and its dry hay yields were about half of the fertilized squares. In the fourth year, the plant growth changed even on the unfertilized squares. It seems profitable on a very exhausted veldt, to improve the plant growth by fertilizing lightly in connection with fencing (sowing with a good grass species may be important in some cases). During rest time on the camps, iipale ought to be destroyed by ploughing and sowing or by planting vegetation. Trials with valuable native grass seeds would also be to advantage.

In some open districts which were previously forest, windbrakes of the original forest species ought to be planted for soil conservation and also for firewood, until suitable introduced trees and methods for propagating are developed. In many cases, such as the Onayenea veldt, several parallel tracks were used in place of a road because a single track softens very quickly. The second track is needed during the rainy season. Hardening of only one of those loose sand roads is a more desirable alternative in order to stop the dongaformations in such "road districts". Fortunately, veldt-fires are no longer used in middle Owambo. In forests and grasssavannas, veldt-fires have been used nearly every year, but usually before the rains, which is the most desirable time, instead of just after the first good rainfall.

Protecting insect-eating birds and killing corn-eating birds is an old custom. Termites are quite common, but not yet disastrous. Today, the inhabitants should learn to understand the value of the products of cattle and not only the value of lagre herds since large herds can gradually cause grassland areas to become deserts. 


\subsection{Farming}

\subsubsection{Agronomy}

The main crop (millet) and the second crop (sorghum) seem to be very suitable for this area and maize has also been grown, but only on a small scale. Shortage of water, soil description and the general need for plant nutrients and soil improvement are reasons why the yields of all crops have been low in many cases. Smut diseases are very common; Ustillago pennisettii on millet, Sphacalotbeca sorghii with small silver-coloured Aporobage and Polyposporium ebrenbergii with long white sporebags on sorghum. In Nkongo, seed dressing with fungicides has been found to be profitable with millet and even with sorghum. In Owambo, a watering method for seed (sorghum) (DOGGETT 1970) by which seeds are soak for 4 hours in water, drying slowly at first in the shade and later under the strong sunshine, was not known.

Some other symptoms of plant diseases have been found, but not yet studied in detail. Insect injuries were also found and ellworms and virus diseases were found in some plants. Striga bormontbica plants and other root parasites were found on sorghum as well as on legumes. This is rather common where mixed planting is used, instead of plant rotation.

Generally, in the area, millet seeds usually contained poor quality specimens and new varieties of millet were just becoming known. The most used sorghum varieties need a long growing season although some hybrid sorghums, such as NK 222, may be good enough for food but they grow quickly and have high yields. Even some quickly growing rice and maize varieties will give good yields in Owambo-Kawango area.

Some millet and sorghum varieties can be used in haymaking and silage with ordinary lay field plants. They can be especially important since supplementary feeding is part of the year's feeding regime and suitable plants for crop rotation should be found. For irrigated areas, there are many suitable market plants from wheat (irrigated wheat has given 3 yields/1 year at Okawango river) to rice, sugar cane, sun flower and cotton. But which would be the best plants in dry cultivation? For instance, sisal is too sensitive for the brack content of soils and the long dry periods (LOCK 1961). There are many kinds of good legume plants in common use and these may be quite profitable and very important for the inhabitants as a protein supply. Some common legumes, such as ground nuts and soya beans are grown but some of these need a regular water supply, for example soya (NORMAN 1963). Sunflowers can suffer a little during the drought periods, but just in these conditions, the plants are usually very healthy and they grow well even in slightly alkaline soils. Rice needs lime, water and heat to grow in some valleys, provided it is possible to organize cultivation with some new short growing varieties. Manihot sp. grows well in Nkongo. There are many subtropical and tropical cultivated plants, but their suitability should be studied further.

Obtaining suitable agricultural machinery, will depend mostly on what is to be grown. One type of Finnish mill with special parts was suitable for millet and also, a Finnish thresher may be more suitable than some other types. Big tractors work well, but small garden tractors with a plough only sink into the loose sand and can only be used to harrow or cut grass on an even veldt. Once the crops have been 
harvested there is a need for new storages to be designed or existing ones reorganised since the present system is not wholly efficient.

\subsubsection{Gardening}

Vegetables, beans, pumpkins, water melons, tomatoes etc. have already been an important part of the food in these areas. However some questions, appear, for example: What is the value of early cultivated and uncultivated vegetables, compared with vegetables known elsewhere?

Which new vegetables are suitable for adoption in this area and which of the old uncultivated vegetables are valuable enough to take into common cultivation?

Can new propagation methods, such as container planting (paperpots) or shades, help to produce profitable results in this climate?

What might be the best means of propagation, growing, harvesting and conservation and marketing methods?

Fruit growing is already common. In the west paw-paw (Carica papya) is common but needs careful irrigation and shade only at the seedling stage. Later, it grows without any help although better yields are gained by watering and fertilizing. Guava (Pisidium Guayava) is another easy fruit tree to establish which does not need large quantities of water, the animals do not eat it and it can be propagated with shoots or cuttings and it can be grown together with limes and lemons (Citrus aurantifolia and C. linonia) in wooded districts, such as Uukuanyama and other northern parts of the area. Even though many other trees have been cut down, many local fruitbearing trees; baobab (Adansonia digitata), bird plum (Phyllogeiton discolor), marula (Sclerocarya birrea), wild fig etc, have been saved in the fields of nearly all the inhabited areas and in some cases, these give special characteristics to different districts and many fruits from other native trees and shrubs are also used (even though the real values of these are unknown, they seem to provide important vitamins, minerals and even some oils). In these areas it seems possible to grow most subtropical and many tropical fruits with low frost susceptibility only if there is water enough for irrigation. Citrus species for example, have given good results in the Kawango area.

Near the Kawango river, the Roman Catholic Mission has many good fruit and vegetable gardens for its own use and the Lutheran World Federation has made available some help for the Owambo-Kawango Church garden in Rupara in order to help and inspire the church members to develop their own gardens. The Engela Parish Institute has some farming and gardening on their program, although the agricultural component is still undeveloped. In the future, if yields increase faster than consumption, there will be a marketing potential which can be developed. In Southern Africa these are organized by the government through special boards of control.

\subsubsection{Nutritive value of some products}

The diet of African people may be cited as an example of healthy food for humans with low mineral supply if their herbs are forgotten. When comparisons are made (Table 9) by analyses of different products, both sorghum and millet have lower 
mineral contents than whole grain wheat but anyhow higher than refined products. Particularly, the use of many species of herbs e.g. "oomboga" with millet porridge as sauce provides an abundant mineral supply to the inhabitants of the area. It is important to encourage the continued use of all the nutritive plants especially since there will be increased pressure to change diet patterns towards the refined products of industrialised countries. By both milling and bounding, the shelling ought to be kept to a minimum in order to keep the nutritive value of the meal as high as possible (Table 9 and Fig. 13, MARJANEN and SOINI 1972, 1977).

\subsubsection{Forestry}

All of the Owambo-Kawango area was once a forest savanna, however, the increasing population cut down trees for firewood and particularly, for houses. Now there are large open districts in the central areas, in the southern areas and western

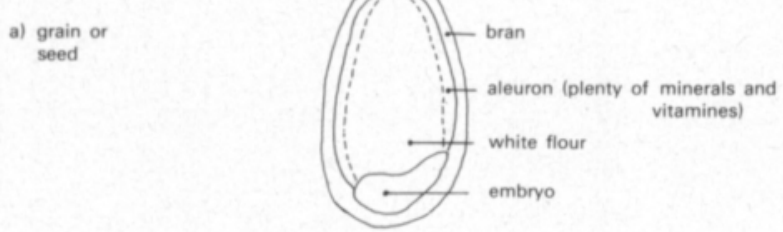

b) Mineral supply in two different diets per day on eqwal energy producing levels

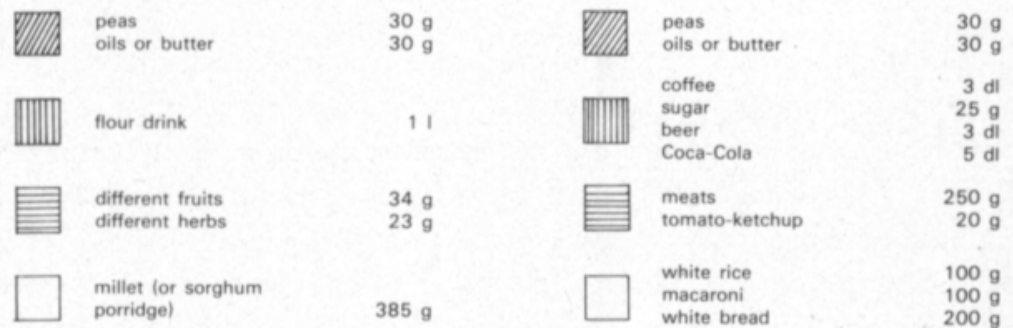

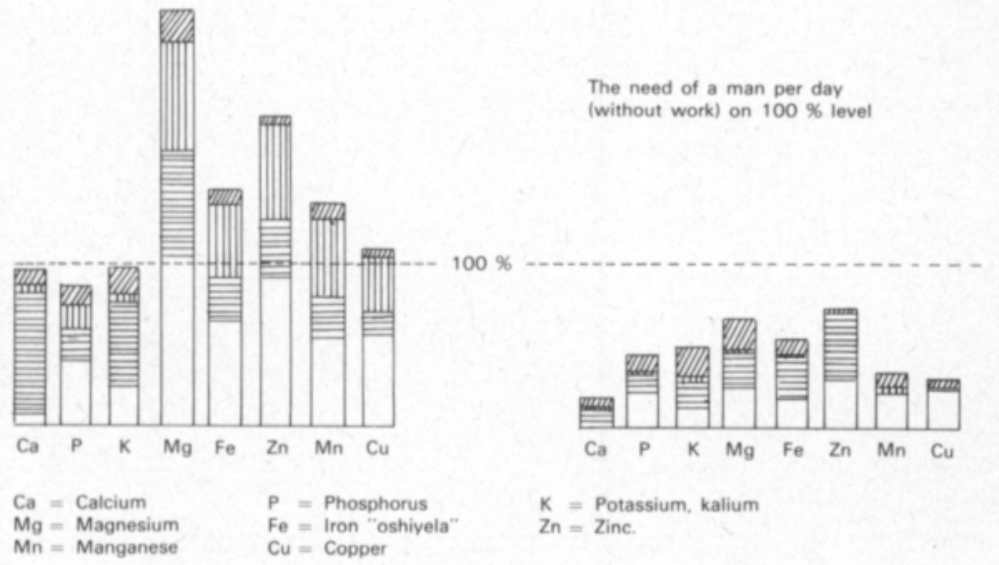

Fig. 13. Mineral supply in different foods. 
Table 9. Mineral contents of some different product samples of Owambo compared with some others (analysed by Viljavuuspalvelu Oy in Finland 1970-76).

$$
\mathrm{g} / \mathrm{kg} \text { of dry matter } \mathrm{mg} / \mathrm{kg} \text { of dry matter }
$$

\begin{tabular}{|c|c|c|c|c|c|c|c|c|c|c|}
\hline Sample & $\mathrm{Ca}$ & $\mathbf{P}$ & K & $\mathrm{Mg}$ & $\mathrm{Fe}$ & $\mathrm{Zn}$ & $\mathrm{Mn}$ & $\mathrm{Cu}$ & Co & Se \\
\hline \multicolumn{11}{|l|}{ Bread } \\
\hline White wheat') $\ldots$. & 0.311 & 1.19 & 1.80 & 0.27 & 73.6 & 11.0 & 4.8 & 1.88 & & \\
\hline Whole wheat ${ }^{1}$ ) $\ldots$. & 0.400 & 4.40 & 5.70 & 1.60 & 57.2 & 39.5 & 54.6 & 4.50 & & \\
\hline $\begin{array}{lll}* & 2\end{array}$ & 0.941 & 1.36 & 0.46 & 1.30 & 89.6 & 32.1 & 40.5 & 3.40 & 0.06 & 0.06 \\
\hline \multicolumn{11}{|l|}{ Flour } \\
\hline White wheat $\left.{ }^{1}\right) \ldots$ & 0.140 & 0.97 & 1.08 & 0.18 & 0.39 & 0.59 & 0.45 & 0.11 & & \\
\hline Whole wheat ${ }^{1}$ ) $\ldots$. & 0.383 & 3.81 & 4.07 & 1.33 & 32.40 & 38.30 & 42.00 & 5.39 & 0.032 & 0.01 \\
\hline Barley $^{1}$ ) $\ldots \ldots \ldots$ & 0.410 & 3.22 & 4.92 & 1.17 & 4.49 & 3.56 & 1.7 & 0.67 & 0.004 & \\
\hline Sorghum, milled ... & 0.78 & 1.24 & 0.36 & 1.30 & 53.9 & 17.2 & 18.0 & 2.0 & & \\
\hline$"$, pound .. & 0.420 & 3.33 & 4.50 & 1.38 & 33.6 & 29.2 & 16.0 & 3.3 & & \\
\hline$" \quad$, malt $\ldots$ & 0.182 & 1.18 & 0.48 & 1.3 & 283.0 & 26.0 & 25.5 & 3.0 & & \\
\hline Millet, milled .... & 1.102 & 1.36 & 0.39 & 1.2 & 54.7 & 38.6 & 14.5 & 3.7 & 0.14 & 0.05 \\
\hline- ,pound $\ldots$ & 0.066 & 0.94 & 0.16 & 0.6 & 55.8 & 37.2 & 8.0 & 1.8 & 0.08 & 0.01 \\
\hline \multicolumn{11}{|l|}{ "Omboga"3) } \\
\hline Dried leaves ...... & 51.050 & 16.46 & 41.8 & 12.4 & 275.0 & 185.0 & 90.3 & 11.5 & & 0.06 \\
\hline "Omakaka" ...... & 32.090 & 6.7 & 38.4 & 5.4 & 309.0 & 165.0 & 76.7 & 9.7 & & 0.05 \\
\hline Good sausages ...... & 1.960 & 4.85 & 4.87 & 0.68 & 35.0 & 38.0 & 1.4 & 2.3 & & 0.06 \\
\hline $\begin{array}{l}\text { Bird plum fruit, } \\
\text { "oombe" soup ........ }\end{array}$ & 3.070 & 0.60 & 21.0 & 1.8 & 19.8 & 14.0 & 13.5 & 1.3 & 0.09 & 0.01 \\
\hline
\end{tabular}
1) Product of Finland
2) Product of Afganistan by E.K. Virri
3) "Omboga" sp Gynandropsis gynandra, usually cooked and dried to "omkaka" cakes

parts of Owambo as overgrazing and continuous cultivation without effective soil conservation have continued. Nevertheless, in the existing large forest areas, there are many valuable trees suitable for furniture and other building purposes, e.g. "Omunhongo" (Spirostachys Africanus), "Omguya" (Pterocarpus Angolensis, Angolan kiaat) and "Omupapa" (Baikiaea plurijuga or Rhodesian kiaat), "Omuandi" (Diospyrus mespiliformis Transvaal ebony), "Omuntundungu" (Erythrophleum Africanum, Owambo kiaat), "Uusivi" (Guibourtia coleosperma, Rhodesian mahogany) and many others. Trees are used by the Government and the natives in buildings, in the new Owambo furniture factory and other woodwork shops. There is no propagation in the area yet. Some Owambo herdsmen believe that the animals do not feed on the young trees but all the most valuable young trees seem to browsed over. It will be advantageous for the whole population to propagate valuable trees both individually and at the government level. Propagation methods may include thick branches of omuguya as cuttings and makalani palm fruits prepared with hot water. Trees are very important for home use. Trees can represent a method of attracting outside markets and are also a valuable nutrient source.

\subsubsection{Animal busbandry}

The Owambo-Kawango area is a mixed grazing land veldt. With the rapidly growing population, however, it will not provide enough natural grazing land for 
animals although veterinary help has already been given by the government and some efforts in solving the pasture problems have been made. These should be implemented as soon as possible, for erosion is already existing in many overgrazed districts. Pastures are not in private ownership, but some rest camp systems could nevertheless be organized regardless of whether this means the usual agricultural reform or the co-operative work of common pastures. Radical changes of course may be difficult to implement since methods in animal husbandry are new to the inhabitants.

In the extensive grazing system all cows calve in the beginning of the rain season but not every year, and calves are not weaned resulting in reduced milk levels available to the villages. The cows may be in large herds outside villages and in the hot climate the milk cannot be transported far so milk is usually made into butter and sourmilk, and stored until taken to the village. Later in the summer when cows are within the village confines the milk production is no more abundant and during the dry season the animals again have to be taken in large herds away from the village to dry grass areas to survive the dry period.

The number of cows and the way of living are important for inhabitants. The balance of energy, products and the carrying capacity of the country has generally been achieved, however, the situation is changing with population growth. In addition to considering profits and level of manual work it is necessary to consider contenment in an effort to discover new methods of cattle farming that are more pleasant, profitable and realistically planned within the limited area of the country. For example, pasture camp arrangements show some benefits in reduction of work and better pastures containing more valuable grasses. In most densily populated areas it will be necessary to try new grass cultivation, hay and silage methods connected with smaller grazing camps for animals and roofings for milking, shade and supplementary feeding.

In one trial, an ordinary cultivated field gave hay yields which could be calculated, that $1 / 2-1$ ha is sufficient for one animal head in the dry season but trials with natural grass cut at the beginning of blossom, gave only one fourth of that. According WEBSTER and WILSON (1966) it is possible to receive a nearly double carrying capacity for Acacia thickets using correct clearing and grazing. Valleys with high plant nutrient soils will offer good pastures if overflow waters are stored in storage dams and better grass species are planted, instead of hard oshanagrass.

Fodder trees, such as the anatree (Acacia albida) with its annual yield of $500-$ $1000 \mathrm{~kg}$ pods are valuable as shade trees. Large trees with long roots can extract important minerals from deep layers. Goats especially are fond of food from trees and bushes, and the milk has been useful in replacing cows' milk in some individual's diet where allergies exist. Sheep for wool production were found in western regions only obviously because of the danger of parasites on the other areas with more abundant rains.

Breeding of the most suitable animals should also be taken into consideration, for example, zebu cattle in the hot climate, West Owambo native cows, abundantly milking goats etc. Obviously any kind of animal, work oxen, donkeys, horses, pigs and even poultry will live and produce more effectively with improved feeding and shelter arrangements.

Honeybees can be recommended as suitable domestic animals in the region 
where some plants are in blossom all year round. Honey is healthier than sugar which in some cases is used excessively in the region. Fishing both in rivers and on the oshanas, provides important proteins, however, it is necessary to find an effective method of preventing overfishing and to initiate a breeding program.

\subsection{Domestic economy}

In heathen times, agronomy and housekeeping were the women's responsibility and animal husbandry was controlled by the men, because of the danger caused by wild animals, initially but later because of heathen religion customs. Now within the Christian law, there are no compulsory differences in duties only efforts to find ways to produce all the necessities for the family, church and for those who might be in need of help.

Needs have changed considerably with increasing knowledge, but the resources in the area are still scarce (usually $1-2$ men of every family are on contract work). The Ongwediva vocational and Ogongo argicultural schools planned by the government, can help on the professional level. The school for basket work at Olukonda, the Department of People's Institute at the Engela Parish Institute and the Rupara garden have been organized to help people improve their handicrafts, farm production and learn to achieve a balance between their wants and needs. There are many possibilities within domestic activities to improve and expand production such as weaving carpets out of old clothe (this was started by Miss Soikkeli at Engela hospital) or with cheap Karakul wool with home made colours. It is not clear, yet, which are the most suitable cultivated fiber plants in the area or which methods can be used in preparing warp thread from "omasigo" or other fiber plants.

Sewing, knitting, pottery, baking, fruit conservation, candy making etc. are suitable for home industry, as well as, work in farming or as an independent yearround business for home family members. Most of these are known, but can be developed in addition to new ideas which may appear. In spite of the mentioned interim efforts, it will be important for the home economy balance to make farming and food production work more easily, and productively, because of the uneven climate (on a new Nkongo bushman farm, mechanical planters resulted in better germination for the crops if compared to the ancient sewing method). There are many questions concerning such aspects as suitable machines for the soil, plant cultivation, exploitation of natural resources and the welfare of the people. For example, a small tractor can be unsuitable for the soil and a big tractor too expensive for a small field so the decision will depend on the people concerned, whether some kind of co-operative owneship or the chance of working on other farms will give the best results. Pasture camps may be started with a "kibbutz or moshaw" system (total or partial co-operative ownership) or with family style units, and these can be developed into some kind of wholesale production and supply and market units. 


\subsection{Markets}

There has been some small scale external markets allowed for wood, furniture, handicrafts and leather. Agricultural products, however, have had their markets within the area only for schools, hospitals, clinics and offices with some imports to the area as well, but there ought to be even outside markets for own products.

\subsection{Human factors}

Within the area there are natives, representatives of the South African Government and some missionaries. The natives have their own government, but it is still under guidance of the South African Government. The South African Government is completing its large development programs gradually with the old tribal ownership systems still existing which make individual developments quite complicated. More than half of the natives are church members, but even these are not all willing to adopt all ideas of the Government.

The independent Owambo-Kawango Church has realized that the help from the South African Government will not be effective for the people, unless they themselves work too and with such a consideration different Missionary Societies have worked in the region. The Lutheran World Federation has organized community development (CDS) projects such as an agricultural survey (19651968), the specialist group from Finland (1966), director-general Prof. J. Vuorinen from the Agricultural Research Centre, Prof. P. Kaitera and others who prepared the plans for a Bushman settlement in Nkongo, the Rupara garden and the Engela Parish Institute expansion with the People's Institute Department. These plans were accepted by the LWF, with a "tractor-trailer and plough for every denary", as CDS projects, which were completed by Rev. M. Ihamäki (FMS) and Mr. R. Knutson (LWF). Further developments towards real economic change, will depend on many things, one of which is the political climate, but in any new program in any country, without an understanding of the need for personal freedom and the sense of responsibility towards other human beings at goals will be impossible to reach.

\section{Recommendation}

Many suggestions have already been made for farm life improvements, most of them not being ready-made programs, but aspects needing further study organisation and trial. After living for five years among the Owambo-Kawango people (the last two years as a teacher at the Oshigambo school and at the Engela Institute) and at a time when the political climate was cooling, the author concluded, that mandatory regulations and instructions were not needed but there was the need to inspire the people to use their own knowledge and skills. Thus in connection with this project some recommendations can be outlined to the Owambo-Kawango Church.

The Church's economic projects, the CDS-projects of the LWF and FMS 
(Nkongo, Rupara, Engela and "tractors for deaneries"), concerning the agricultural sphere should be evaluated and guided further with realistic goals.

The Church organizations and individual members can (in spite of political difficulties) adopt some of the above suggestions. There are pastors, teachers, deacons, youth leaders and clever farmers, who are able to co-operate in making programs suitable for their own areas and circumstances. Ideas in technical or scientific help may be needed in obtaining material for trials and for interpreting those results which may differ from the expected. Particularly for young people, the discovery of new techniques forms and formulation of new programs and plans will be more interesting than any readymade programs. In European systems, agricultural societies and 4-H clubs which have experimental activity, do not have any religious affiliation. However, why divide the lives of the church members, who are nearly all farmers? When sewing circles work for the mission, why not have different kinds of farming or gardening circles? Boy scouts and girl guides are encouraged to "do one good deed every day", so why not plant one valuable tree or break some "iipale"? In addition, for young learned people, there could be opportunities for scientific studies. For conditions similar with this area, there is no simple method of "green revolution" but, as a result of the above studies, a list of subjects which deserve attention is presented:

1. Water conservation:

- water reservoirs for home use, for animals during the dry season and for irrigating purposes in the dry periods of the, rainy season

- water conservation in the soil

- shades and paperpots, grass mulch, etc. for growing seedlings

- wind breaks

2. Plant nutrient supply and soil improvement in cultivated fields:

- plans for increasing humus:

latrine and sewage compost

farmyard compost

green manure and plants

plants for leys

crop rotation plants

ploughing in crop residues and other organic material

harrowing in weeds - grass mulch

wood humus

- micronutrients important in artificial fertilizing

- organic fertilizing only or together with artificial fertilizers

- studies involving the most valuable valley soils

- studies concerning lime layers of "iihenene"

3. Soil improvement of pastures:

- rest camps

- fertilizing

- breaking "iipale" with or without planting, fertilizing, sowing and fencing

- furrows across the slopes

- weed bushes for wood humus

- planting shades, wind breaks, fodder trees or bushes

4. Agronomy:

Ploughing

- method (mulch tillage, tie-ridging, usual or minimum tillage) time, working power, depth (not to brack layers)

Planting

- seeds, shortgrowing varieties, seed dressings 
- fertilizers (amounts and quality)

- depth of seeds, time of sowing

- rows (direction)

Harrowing

- walls, ridges and ties

- speed and quality, tools

- best time (eg. after the rain), number of times

Symptom observations

- plant nutrient deficiencies

- diseases and parasites

- insects and animals

Protection without pollution

Harvest

- machinery for millet corn

- machinery methods and implements for hay and silage

Storage

- maintaining dry home grain storages and improvement of the methods

- common storages and mills for the district (valuable meal, not "white")

- storages for hay and silage

New plants and their cultivability in the Owambo-Kawango area

- for humans, animals and markets

5. Gardening:

- suitable vegetables and their cultivation

- suitable fruits and their cultivation

- time, techniques and fertilizing

- tools and machinery

- plant protection methods

- harvesting and use

- different irrigation methods

- nursery help

- dry cultivation methods, shades, coverings etc.

6. Forestry:

- trees of the area and their value

- propagation of valuable trees, seeds, nurseries, planting methods

- forest protection

7. Animal husbandry:

- grasses of the area their nutritive value

- pasture improvement: thicket clearing, rest camps, pasture plants, fodder trees and their propagation, ridges on hillsides, drainage of valleys, water dams and irrigation

- cultivated fodders and their use for different animal production

- new animals and selected native animals

- animal husbandry at home or as a co-operative enterprise

- fishery, resources and development

- beekeeping

8. Social life in agriculture:

- land tenure systems and how to continue with the increasing population

- animal ownership and limitation on livestock numbers

- machinery systems, ownership questions

- water and soil conservation organizations

- pasture camp organizations

- plant protection

- veterinary assistance (is in operation by the SA Goverment)

- forest propagation and ownership questions

9. Market questions:

Agriculture and gardening

- home markets, common mills and corn storages, vegetable and fruit markets and conservation

- new products from crops, eg. juice, "omahuku-oil" etc. 
- new plants for home use, markets or fabrics, fiber plants, eg. manihot, sunflowers etc.

- new products with irrigation and their markets, eg. soya ground nuts, rice, cotton, vegetables, fruit etc.

Forestry

- wood markets, wood workshops, wood humus (wood residues and weed bushes)

Animal husbandry

- meat market, storage, leather industries, dairies, poultry products, honey

Home industry

- bakery and other food products, baskets, woodwork, pottery, carpets, printing, music records and tapes etc.

10. Energy:

- electricity

- solar energy

- energy production, energy forests, maniok etc.

\section{Summary}

During the agricultural survey of Owambo and Kawango in 1965-1968 (70) and in connection with it, certain topics have been observed and discussed, and they can be summarized as final comments in this report.

The climate in the area is moderately suitable for many sub-tropical and some tropical plants. There are limiting factors which include the four months of irregular and heavy rains (average annual $400-600 \mathrm{~mm}$ ), the considerable fluctuations in the temperature (average annual $15-25^{\circ} \mathrm{C}$ ) and the night frosts occurring in some years.

The soils of the area consist of Kalahari sands which vary from grey to red, with catenary sequences from deep loose finer coarse to fine sand mixtures, with loam and clay mixtures in depressions and calcium accumulations in subsoils. The soil reaction sequence is from weakly acid to occasional strong alkaline. All the uplands are poor in humus and plant nutrients but are moderately suitable for mixed farming, the limiting factors being shortages of water, humus and plant nutrients. The loosest parts of the uplands are recommendable reserves depending on meaning as protection forests. The valley soils vary between moderately fertile to poisonously brackish. Some of them are moderately suitable for mixed farming and for soil improvement and thus ought to be studied further.

Soil conservation efforts, conservation of soil water for the cultivated plants and also in the underground reserves by preventing run-offs and limiting evaporation are very important and there are opportunities to work in many ways on both the small and large scale.

The development of canals, dams, and waterpools together with improved knowledge concerning new undersurface watering methods connected with fish propagation in waterpools ought to be followed. However protection against accumulation of salts and spreading of bilharziaris will be needed, especially if open canals are used. Together with this, research in soil improvement methods (both natural and artificial) to increase humus and restore nutrient balance to widely differing soils is important.

The organization of alternative watering methods can offer opportunities to adopt many new plants in cultivation which may significantly affect gardening (e.g. with watering, shades, new and native plants and organization of markets or 
conservation of products) fruit production and animal husbandry. At present only small scale reforms are available for an individual farmer since owing to the land tenure system, some changes and effective co-opetative efforts are needed only when meat production ought to be increased. Some new short-growing varieties of established cultivated plants, totally new variations, will make dry cultivation and use of some machinery easier and more profitable.

Forestry has been controlled by those who have had opportunities to harvest the trees and this situation eill propably continue. It will be profitable to assure controlled harvesting and organize the propagantion of the many valuable trees of the area with evaluation of the different usages and productivity of the mopane trees in the western areas.

Suitable implements, buildings, storages, conservation methods and machinery will be needed according to the development and increase in products and markets, within the area.

The handicraft industry, both as interim work and permanent work, could help to balance an economic situation for example, in the marginal dry farming areas, if markets are organized.

The present stage of farming, existing in the area now, consists of simple plough cultivation with little use of farmyard manure, connected with pastoralism. Such a system offers considerable opportunities for changes and further development even though the possibility of failure of such projects must be recognised. However if goals are realistic and development is controlled, the area can provide higher living standards for even larger populations than today.

\section{References}

AALTONEN, V. T. \& AARNIO, B. et al. 1949. Maaperäsanaston ja maalajien luokituksen tarkistus v. 1949. Summary: A critical review of soil terminology and soil classifications in Finland in the year 1949. Maatal.tiet. Aikak. 21: 37-66.

ANON. 1961. Publication of South West African Water Affairs. January 1961. No. 11. 4309. g091962-1963. Reports of the Commission of Enquiry into South West Africa Affairs 1962-1963. Pretoria.

- 1964. Geological map. South West Africa.

BARNARD, W. S. 1964. Die Streekpatrone van Suidwes-Afrika. Dissertation, Stellenbosch University.

- 1966. Waterbewaring in Ovamboland: N Geografiese studie. Oordruk Acta Geographica p. 79-95. Kaapstad.

BOOYSEN, C. R. 1966. Landboukunde vir seniors. 366 p. Kaapstad.

BRIDGES, E. M. 1970. World soils. 89 p. Cambridge.

BROWN, K. J. 1963. Rainfall, tie ridging and crop yields in Sukumaland, Tanganyika, Emp. Cott. Grow. 40: 34-40.

COOKE, H. B. S. 1964. The pleistocene environment in Southern Africa. Ecological studies in Southern Africa by Davis, D.h.s. \& al. p. 1-23.

DOGGETT, H. 1970. Sorghum. 403 p. London.

HAMILTON, G. N. G. \& COOKE, H. B. S. 1960. Geology for South African Students. An Introductory Textbook. 441 p. 4th Ed.

KURKI, M., LAKANEN, E., MÄKITIE, O., SILLANPÄÄ, M. \& VUORINEN, J. 1965. Viljavuusanalyysien tulosten ilmoitustapa ja tulkinta. Summary: Interpretation of soil testing results. Ann. Agric. Fenn. 4: 145-153. 
LOCK, G. W. 1961. Sisal. Twenty-five years' sisal Research. Tropical Science Series. 355 p. London 1962.

MARJANEN, H. 1969. Possible causal relationship between the easily soluble amounts of Manganese on arable mineral soils and suspectability of cancer in Finland. Preliminary report. Ann. Agric. Fenn. 8: 326334.

- \& SOINI, S. 1972. Possible causal relationship between nutritional inbalances especially manganese deficiency and susceptibility to cancer in Finland. Selostus: Mahdollinen syy-yhteys ravinnetasapainohäiriöiden, etenkin mangaanin puutteen ja syöpään sairastumisalttiuden välillä Suomessa. Ann. Agric. Fenn. 11: 391-406.

_ \& SOINI, S. 1978. Kivennäisaineiden ja vitamiinien merkityksestä. 237 p. 2nd Ed. Kaarina.

McALISTER, J. T. 1962. Mulch tillage in the Southeast. Planting and Cultivating in Crop Residues. U.S. Dep. Agric. Leaflet No 512.

McCHIE, D. A. 1979. Managing water-repellent soils. J. Agric. W. Australia 20.3: 78781.

NORMAN, A. G. 1963. The Soyabean, Genetis, Breeding, Physiology, Nutrition, Managements. Academic Press Inc. 239 p. London.

PAPADAKIS, J. 1969. Soils of the World. 208 p. Amsterdam.

ROIVAINEN, H. 1974. Contribution to the flora of South West Africa. Ann. Bot Fennici 11: 231-249.

ROSE, E. F. 1968. The Effect of Soil and Diet on Diseases. Cancer Research 28: 2390-2392. Transkei South Africa.

SYMMONS, L. 1968. Agricultural Geography. 283 p. London.

VINE, H. 1966. Tropical soils. Agriculture in the tropics by Webster, C. C. \& Wilson, P. N. p $28-67$.

VUORINEN, J. \& MÄKITIE, O. 1955. The method of soil testing in use in Finland. Selostus: Viljavuustutkimuksen määritysmenetelmästä. Agrogeol. Publ. 63: 44.

WEBSTER, C. C. \& WILSON, P. N. 1966. Agriculture in tropics. 488 p. London.

Ms received July 9, 1981 . 


\title{
Maatalous Pohjois-Namibiassa, Ambomaalla ja Kawangolla 1965-70
}

\author{
Sylvi Soini
}

Maatalouden tutkimuskeskus, 31600 Jokioinen

Luterilaisen maailmanliiton toimeksiannosta suoritettiin maataloudellista perustutkimusta PohjoisNamibiassa, Ambomaalla ja Kawangolla vuosina $1965-68$ ja kertynyttä aineistoa täydennettiin AmboKawangokirkon ja Suomen Lähetysseuran toimintaan liittyvän maatalouden opetustyōn ohella vuosina 196970.

Tarkoituksena oli antaa kirkolle selvitys sen toimialueella harjoitetun maatalouden tilasta ja kehittämismahdollisuuksista sekä kytkeä kouluissa annettavaa maataloudellista perustietoa paikallisiin olosuhteisiin.

Alue sijaitsee kauriin kääntöpiirin pohjoispuolella Namibian ja Angolan rajalla. Se on hiekkaperäistä ylätasankoa. Sen ilmasto on lähinnä subtrooppinen ja vaihtelee semiaridisesta subhumiidiseen. Kasvillisuus on metsäsavannia, jonka puusto on enimmäkseen lehtensä karistavia lajeja kuten akaasioita ja mopania, joitakin jalopuulajeja sekä makalanipalmua.

Alueen asukastiheys on etelān kaupunkeja lukuunottamatta Namibian suurin, paikoin yli 8 henkeä $/ \mathrm{km}^{2}$. Pääelinkeinot ovat maanviljelys ja karjanhoito. Ansiomahdollisuudet ovat heikot ja pääasiallisesti alueen ulkopuolella, joten alueen oman elinkeinoelämän kehittäminen on tarpeen.

Tutkimuksessa tarkastellaan sekä kirjallisuudesta saatavissa olevia että mahdollisesti sovellettavissa olevia yleistietoja. Lähempiä tietoja alueen kasvillisuudesta hankittiin keräämällä kasvinäytteitä, jotka määritettiin Helsingin Yliopiston Kasvitieteen laitoksella sekä Windhoekin kasvimuseolla. Tutkimuskauden aikana tehtiin haastatteluja maatalouden sen hetken tilanteista ja järjestettiin joitakin havaintokenttiä.

Varsinaisena perustutkimuksena alueella suoritettiin pääpiirteittäinen maaperätutkimus soveltaen joitakin suomalaisen maaperäkartoituksen menetelmiä käytännöllisen viljavuuden selvittämiseksi. Maanāytteitā kerättiin 120 pisteestä, niistä 76 kolmesta syvyydestā, 283 näytteestä määritettiin viljavuusluvut ja 64 nãytteestã raesuuruudet sekä liukoisten hivenaineiden määrityksiä tehtiin 59 ja totaalimäärityksiä 46 pintamaanäytteestã Maatalouden tutkimuskeskuksen maantutkimusosastolla. Lisäksi saatiin vertailua varten 115 näytteestã eteläafrikkalainen viljavuusanalyysi, sillã suomalainen menetelmã on kehitetty lähinnã lievästi happamille maille soveltuvaksi.

Analyysitulokset eri menetelmillã olivat pääasiassa samansuuntaisia ja seurasivat lähes johdonmukaisesti maan pintamuodostuksista ja kasvillisuudesta pääteltävissä olevia suuntauksia. Ylävät maat olivat yleensã ravinneköyhiä, huuhtoutuneita, lievästi happamia ja suuri osa niillä olevista peltomaista oli raesuuruuksiltaan vain vālttãvästi peltoviljelyyn sopivia. Alavat maat olivat yleensã enemmän kivennäisaineita sisältäviä, mutta usein heikosti läpäiseviä ja yliemäksisiä, toisinaan reheväkasvuisia toisinaan aivan kasvuttomia.

Maaperämuodostumia on kuvattu erilaisina piirroksina ja niihin liittyvistã raesuuruus- ja viljavuusanalyysien tuloksista on laadittu sekä keskiarvotaulukoita että niihin liittyviä piirroksia.

Maaperätutkimuksen ohella tehtyjen havaintojen, havaintokenttien, kirjallisuustietojen ja haastattelujen perusteella on tarkasteltu vesi- ja kasvinravinnetilanteen hoidon ja erosiotorjunnan menetelmiä sekä maatalouden eri alojen edistämisen mahdollisuuksia alueella. Samalla on lyhyesti huomioitu joitakin maa- ja kotitalouden teollistumiseen liittyviä tekijöitä. Lopuksi on esitetty mahdollisten alueen maataloutta kehitettäessä huomioon otettavien seikkojen yhteenveto. 